\title{
„Mi életfogytiglani, vagy rezsimfogytiglani kényszermunkások vagyunk." Emlékek az 1952. májusi nagyatádi kitelepítésről
}

\author{
HAUPTMAN GYÖNGYI \\ Nagyatádi Kulturális és Sport Központ - Városi Múzeum, H-7500 Nagyatád, Széchenyi tér 2., \\ e-mail: hagyongy@gmail.com
}

\begin{abstract}
HAUPTMAN, GY.: „We are forced labourers with a life sentence or regime sentence." Memories about the relocation in Nagyatád, May 1952.

Abstract: More than 70 people, 26 families were deported from Nagyatád to one of the forced labour camps of Hortobágy in Elep in May 1952, during the communsist dictatorship. Relocations/deportations were performed without any indictment or court judgment and meant total confiscation of property for the people concerned. The deported families were forced to work in labour camps deprived from their civil rights, under inhumane conditions and under police custody. In my study I present the history of the deportation, the everyday life of the deported and their life after their disengagement from captivity by analyzing personal resources - letters written during the relocation, subsequent recollections.
\end{abstract}

Keywords: communist dictatorship, deportation, forced labour camp, personal resources, borderland

\section{Bevezetés}

„Már egy éve volt, hogy a saját házukból a Barakonyiházba költöztették Dr. Veress Dezső ügyvédet és családját, mert a Széchenyi tér 4-et a Belügyminisztérium tüzoltó laktanya céljára lefoglalta. (...) 1952. május 29-én éjjel 2 óra körül géppisztolyos egyenruhások dörömböltek az ablakon, s a család munkabíró részét: édesapámat és anyámat, Veress Dezsőt és feleségét, Erzsit egy fél teherautónyi személyi holmival a nagyatádi vasútállomásra szállitották, ahol egy ott veszteglő vonatszerelvény egyik tehervagonjába zárták B. G.-ékkal és a henészi Cs.-ékkal együtt. A szerelvény még sok hasonló »rakományúu marhavagonból állt. Nővéremmel (Judit) és nagymamámmal (Anyuka, Tilda) a lakás másik szobájában maradtunk, a szüleimét hatósági pecséttel lezárták. Az ott maradt holmikat később elárverezték. Én akkor 12 éves voltam, nővérem 13, nagyanyám 66 éves volt.

A vonatba zártak további sorsát az alábbi levelekből ismerhetjük meg. A menet közben kidobott levelek ${ }^{1}$ közül csak egy maradt fenn." (...) (VP 2003. február)

A 2000-es évek legelején Veress Péter és testvére, Bodnárné Veress Judit felajánlották a nagyatádi Városi Múzeumnak a Veress család mintegy kétszáz évet

1 Az elhurcoltak a vagonokból kidobott cédulák, levelek révén próbáltak üzenni hozzátartozóiknak. Egyik interjúalanyom mesélte, hogy nagyszülei a somogyszobi állomáson „Hortobágyra visznek" tartalmú cédulát dobtak ki a vagonból, s ráírták a nevet, címet, ahová kérték, hogy feladják. Az üzenet célba ért, bár azóta - sajnos - elveszett.

2 Veress Péter 2003. februári levelének részlete. átívelő irattárának több száz darabját (okiratokat, magán- és hivatalos leveleket, leltárakat stb.). A csodálatosan rendezett dokumentumok több részletben érkeztek a múzeumba, 2003 februárjában egy körülbelül száz levélből álló csomagot kaptunk. A levelek zöme 1952. május 30. és 1953 novembere között íródott, valamint néhány későbbi levél és egyéb dokumentum kapcsolódott még hozzájuk. A csomag mellé csatolt jegyzéken Veress Péter néhány mondattal világította meg a levelek családtörténeti hátterét - ebből származik a fenti idézet.

A levelek végigolvasása döbbenetes és megrázó „időutazás” volt számomra: ekkor szembesültem először - közvetlen közelröl, a hortobágyi kényszermunkatáborból írt levelek révén, egy család sorsán keresztül - az 1950-es évek elején történt kitelepítésekkel, amelyekről addig éppen csak hallottam valamit. Gulyás János és Gulyás Gyula 1988-ban bemutatott „Törvénysértés nélkül" című filmje volt a témával kapcsolatos egyetlen feldolgozás, amivel korábban találkoztam. S arról, hogy mindez Nagyatádon (és a környékbeli falvakban) is sok-sok családdal megtörtént, egyáltalán nem volt tudomásom. A levelezés megismerése után évek kellettek ahhoz, hogy földerítsem, kik emlékeznek még ezekre az eseményekre, kikkel lehetne még beszélgetni arról, ami történt.

2002 szeptemberében, a kitelepítés 50. évfordulóján Kiss Imréné kezdeményezésére az egykori nagyatádi deportáltak emléktáblát avattak fel a múzeumban. Az ünnepség utáni beszélgetés egyik fő témája az volt, hogy a történtekről évtizedekig nem lehetett beszélni, nem lehetett róla megemlékezni, és ezen még a rendszerváltás sem változtatott igazán. ${ }^{3}$ Még akkor, ötven évvel a kitelepítések, és tizennégy évvel a rendszerváltás után is érezni lehetett az eseményekről való beszéd körüli feszültséget: lehet-e, szabad-e; lehetnek-e még itt „olyan emberek”, akik akkor a deportálást intézték, s van-e még olyan hatalmuk, amivel árthatnak azoknak, akik beszélnek? Számomra ez akkor felfoghatatlan volt. Sok-sok beszélgetés, levéltári és könyvtári kutatás révén tudtam közelebb kerülni a történtekhez, és nem csupán azokhoz, hanem a belölük kibontakozó emberi sorsok megértéséhez is.

A megemlékezésen személyesen találkoztam azokkal az - akkor már - idős emberekkel, akiket családjukkal együtt kitelepítettek Nagyatádról. Közülük kerül-

3 Ezzel kapcsolatban rendkívül beszédes Téglásy Ferenc 1988-as filmjének a címe: Soha, sehol, senkinek. A film egy Budapeströl kitelepített család történetét mutatja be. 
tek ki az első beszélgetőtársaim, és ők küldtek tovább ismerőseikhez, akik fogadtak és elmondták nekem az emlékeiket. Az emlékek felidézése - a sok évtizednyi távolság ellenére is - nehéz és felkavaró volt a kitelepítést átélők számára. Kérdéseimmel, érdeklődésemmel olyan élmények, tapasztalatok felidézésére késztettem őket, amelyek nemcsak a saját, hanem egész családjuk (szüleik, gyermekeik, rokonaik) életét, lehetőségeit, gondolkodásmódját befolyásolták, meghatározták. A beszélgetések révén felmerülő emlékek sokszor csaltak könnyeket a szemükbe, s néha hosszú, nehéz csöndeket okoztak. Ennek ellenére beszéltek róla, el akarták mondani, és megköszönték, hogy megkérdeztem és meghallgattam őket. El akarták mondani, hiszen évtizedekig nem beszélhettek róla, és tudták - ahogy sokszor hangsúlyozták is -, hogy ők az utolsók, akik még közvetlenül emlékeznek a szörnyű meghurcoltatásokra. Emlékezni akartak, hogy emlékeztessenek.

Ebben a tanulmányban a Veress család levelein és a személyes beszélgetések anyagán keresztül mutatom be az 1952. májusi nagyatádi kitelepítés történetét. A levelek és a beszélgetésekből kibontakozó visszaemlékezések egyaránt a személyes források körébe tartoznak, ugyanakkor másképpen idézik fel a történteket. A levelek az eseményekkel egy időben íródtak, ezért az élmények, tapasztalatok rögzítése még közvetlen, rendszerezésük és értelmezésük még nem, vagy csak részben történt meg. Így a kitelepítettek egykorú nézőpontjait képesek megmutatni, amelyekről - a személyes források hiánya vagy egyelőre felderítetlen volta miatt csak nagyon keveset tudunk. ${ }^{4} \mathrm{~A}$ visszaemlékezésekben pedig - a levélben közvetlenül felidézett élményekkel szemben - a történet utólagos újramondása történik meg: a mesélők a kitelepítés óta elmúlt évtizedek tapasztalatain, élményein átszürve beszélik el a történteket. Elbeszélésük emlékidézés, ám egyúttal az emlékek és az elbeszélő életének értelmezése is az életút éppen aktuális pontjáról visszatekintve. Ezért a visszaemlékezés részben felidézi az eredeti jelentéseket és értelmezéseket, részben újakat tesz hozzájuk.

Mire elegendő társadalomtudományi szempontból egy ilyen típusú forrásbázis? Arra semmiképpen sem, hogy általános következtetéseket vonjunk le a nagyatádi kitelepítés menetéről, okairól és következményeiről. Arra viszont egyedülálló lehetőséget nyújt, hogy a szemtanúk perspektívájából vázoljunk fel egy történetet, közelebb jutva így a történelem megélésének privát szintjeihez.

\section{A nagyatádi kitelepítések közvetlen politikai-törté- nelmi háttere}

A Rákosi Mátyás nevével fémjelzett kommunista diktatúra idején (1948-1953) több fajtája létezett a politikai elhatározásokon nyugvó, zömében bírósági tárgyalás és ítélet nélkül, közigazgatási eljárás keretében végrehajtott tömeges meghurcolásoknak. A tízezreket érintő bebörtönzések, internálások, deportálások végrehajtója

$4 \quad$ Lásd ehhez: Kunt, 2015: 205 a politikai rendőrség - ÁVO, később ÁVH - volt, ami a legfelsőbb pártvezetés irányításával müködött. ${ }^{5}$

A meghurcolásoknak létezett egy olyan formája, amely nem egyéneket, hanem egész családokat érintett: az 1950 és 1953 között zajló internálásszerü kitelepítések ${ }^{6}$ sorozata, amelyek során több ezer családot fosztottak meg az otthonától. A budapesti kitelepítések (1951. május 21. - június 18.) célja, több átfogó vizsgálat szerint is, az egykori elit felszámolása volt. A kitelepítés jogalapjául leginkább a háború előtti rangot vagy foglalkozást vették. Fontos szempont volt a kitelepítettek lakásainak, házainak állami tulajdonba vétele, amelyekbe az új rendszer tisztségviselőit, pártfunkcionáriusaikat (a „megbízható kádereket”) költöztették be. A budapestieket kelet-magyarországi településekre (elsősorban Békés, Hajdú, Heves és Szolnok megyékbe), ottani kulákcsaládokhoz internálták. ${ }^{7}$

A kitelepítések másik változata a Szovjetunió által ellenségesnek nyilvánított Ausztriával, és a Tito vezette Jugoszláviával szembeni politikai és katonai intézkedésekkel függött össze, és az ország nyugati és déli határvidékén élőket sújtotta. A határok mentén végig müszaki határzár épült, és létrehozták a határsáv intézményét, ${ }^{8}$ ami $15 \mathrm{~km}$-es mélységben érintette az ott lévő településeket. A kilencezer négyzetkilométeres határsávba hat megye (Csongrád, Bács-Kiskun, Baranya, Somogy, Zala, Vas) tizenöt járása került, háromszáz településsel, háromszázezer ott élő állampolgár-

$5 \quad$ A szervezet 1946 és 1948 között államvédelmi osztályként (ÁVO) müködött, kezdettöl fogva kommunista irányítással. 1948-ban a belügyminisztérium Államvédelmi Hatóságává (ÁVH), 1950-től pedig - a belügyminisztériumtól elkülönült - önálló, országos hatókörü föhatósággá szervezték át, amely közvetlenül Rákosi alá tartozott és az ő utasításait követte. 1950 és 1953 között ez a szervezet volt a pártvezér legföbb támasza a terroruralom gyakorlásában, egy olyan rendszernek a müködtetésében, amely a megfélemlítésre és a félelemben tartásra alapozott. Ebben az időszakban a szervezetnek 35 ezer fös volt a besorozott, militarizált állománya, és 45 ezer embert foglalkoztattak a besúgóhálózatban, élén Péter Gábor állt. A témához lásd: Bank-GyarmatiPalasik, 2012.

6 Hantó Zsuzsa az internálás fogalmát a következőképpen határozza meg: „Az internálás a fennálló társadalmi rendre politikai vagy közbiztonsági szempontból veszélyes, de konkrét bủncselekményt el nem követő egyének őrizetben tartása vagy kijelölt helyen való elkülönítése." Hantó, 2006: 27. A Budapestről és a határsávból kitelepítettek ellen nem emeltek vádat, nem folyt ellenük bírósági eljárás, és nem volt ítélet. A kijelölt személyeket, családokat tisztán politikai szempontból ítélték „veszélyesnek”. Ahogy Saád József fogalmaz, „a hortobágyi zárt táborok őrizetesei, a hozzájuk legközelebb álló kategóriákba tartozókkal: az internáltakkal, továbbá a fővárosból és a vidéki városokból kitelepítettek együtt tisztán társadalomátalakítási célzatú büntetés áldozatai. Ők azok a deklasszáltak, akiknek büntetésében kiemelten fontos szempont volt az elszigetelés." Saád, 2005: 319.

7 A budapesti kitelepítés közel 600 családot, mintegy 13000 személyt érintett. A kitelepítésekkel kapcsolatban lásd egyebek között: Hantó Zsuzsanna: Kitiltott családok. Magyar Ház Kiadó, 2010.; Széchenyi Kinga: Megbélyegzettek. A kitelepítések tragédiája. Kráter Mühely Egyesület, 2008.; Dessewfy Tibor - Szántó András: „Kitörő éberséggel” A budapesti kitelepítések hiteles története. Budapest, Háttér, 1989.; Viczián Zsófia: „Régen lev. lapokon láttam ilyent" Levelek a kitelepítésből Budapestre. Budapesti Negyed 68. (2010. nyár) 162-180.

8 A déli határsávot 1948-ban hozták létre azzal összefüggésben, hogy Jugoszláviát Sztálin javaslatára kizárták a szocialista államok közösségéből, és a jugoszláv kommunista párt vezetőjét, J. B. Titót „az imperializmus láncos kutyájá”-nak bélyegezték. 
ral. A határsávba idegenek csak engedéllyel léphettek be, a helyi lakosok pedig ún. határsáv-igazolványt kaptak, az egyes területek közötti mozgást azonban az ő számukra is megnehezítették. A területen létrejött egy kiterjedt besúgó- és ellenőrző hálózat, amely a nyugati és a déli határ mentén minden mozgást, minden szabálytalanságot azonnal jelentett a belügyi és az államvédelmi hatóságok felé. ${ }^{9}$

A háborús pszichózis légkörében hozták meg azokat az intézkedéseket, amelyek e terület „ellenséges elemektől” való megtisztítását szolgálták. Ennek jegyében 1950. június 1-jére az Államvédelmi Hatóság elkészítette a javaslatot a határsávban élő osztályidegen, ellenségesnek minősített társadalmi csoportok kitelepítésére, megelőzendő azt, hogy egy katonai konfliktus esetén „kémkedhessenek” vagy „szabotázsakciókat" hajthassanak végre. Az intézkedések összefonódtak a Magyar Kommunista Párt falukollektivizálási programjával, ami szintén ekkor tetőzött. Rákosi bejelentette, hogy a „kulákok korlátozásának politikájáról” a „gyökeres elintézés politikájára” kell áttérni. „Talán úgy - mondta -, hogy külön kulákfalvakat csinálunk, mint a Szovjetunióban." ${ }^{10}$ A határsávban élő kulák így többszörösen is veszélyesnek számított a hatalom szemében, rájuk alkalmazták az új helyzetnek megfelelően „feltalált” „titóista kulák” megbélyegző kategóriát. A kitelepítések politikai célja tehát az volt, hogy a határsávot megtisztítsák a párt által ellenségesnek ítélt „osztályidegenektől”, és egyúttal a tisztogatásokkal megfélemlítsék, ledermesszék a helyben maradt lakosságot. ${ }^{11}$

A deportálásoknak emellett gazdasági céljai is voltak. A kitelepítések célterülete az ország keleti vidékein lévő Hortobágy és a Nagykunság északi pereme volt, egy aránylag elzárt, nehezen megközelíthető terület, amely alkalmasnak látszott a pártvezetés által veszélyesnek ítélt emberek elkülönítésére. Ugyanakkor e fejletlen, kevéssé civilizált vidék megfelelő terepe lehetett a szovjet mintára („Szibéria civilizálása”) tervezett nagy természetátalakító kísérletnek. Ez a hortobágyi ősgyep feltörését, a vízrendszer átalakítását, az addig nem müvelt földterület mezőgazdasági termelés alá vonását jelentette, továbbá új termelési ágak meghonosítását (pl. a gyapot termesztését) tűzte ki célul. Itt tervezték először bevezetni és kipróbálni a szocialista típusú nagyüzemi gazdálkodást is. A többszöri átszervezés után létrehozott Hortobágyi Állami Gazdaságok Trösztje vált a későbbiekben megszervezett hatalmas állami gazdaságok elődjévé. Mindehhez óriási, szabadon felhasználható munkaerőre volt szükség, amit a kitelepítésekkel akart a hatalom megszerezni. ${ }^{12}$ A kitelepítéseket továbbá - a budapestihez hasonlóan - gyakran vezérelte a vidéki városi lakáshelyzet megoldatlansága. A deportáltak hátrahagyott házaiba az új rendszer intézményei, közigazgatási, rendészeti, és katonai személyzete költözött be.

9 A határsáv történetéhez: Orgoványi, 2001.

10 Kiss László, 2005: 13-50.; Saád, 2005: 287-326.; Saád, 2010: 4-20.

11 Saád, 2010: 7.

12 Saád, 2005: 287-326.
Az első kitelepítésre 1950. június 23-ának éjjelén került sor a déli és a nyugati határsáv teljes hosszában. A következő évek során, egészen 1953 áprilisáig összesen 45 kisebb-nagyobb kitelepítési hullám követte egymást: részint továbbra is a határsávból (a nyugati és a déli határrészről is), részint vidéki városokból, a határsávon kívül eső településekröl (mint pl. Pécs, Kaposvár, Nagykanizsa, Zalaegerszeg). A határövezet 451 településéről és a nagyobb városokból közel 8000 embert ( 2500 családot) gyűjtöttek össze és kényszerítettek munkatáborokba. A kitelepítést - mint már említettem - minden más büntetési formától megkülönböztette az, hogy nem egyes személyeket, hanem egész családokat, az egy háztartásban élő család minden tagját érintette korra és nemre való tekintet nélkül, a csecsemőtől az aggastyánig. A kitelepítés egyúttal teljes vagyonelkobzással járt együtt.

A deportáltak számára a Tisza magyarországi középső folyása mentén összesen tizenkét tábort létesítettek (1. ábra) ${ }^{13}$, többségüket a Hortobágyon (Szolnok és Hajdú-Bihar megyében). ${ }^{14} \mathrm{~A}$ táborok munkaszervezési és igazgatásrendészeti szempontból a Hortobágyi Állami Gazdaságok Trösztjéhez tartoztak. Az embereket az Állami Gazdaság foglalkoztatta, és ellátásuk is nagyobbrészt a tröszt hatáskörébe tartozott. ${ }^{15} \mathrm{~A}$ területi adottságokból adódóan alapvetően mezőgazdasági munkát végeztettek a kitelepítettekkel. Közöttük sok munkaképtelen idős ember és 14 év alatti, sőt számos, még nem iskoláskorú gyermek is volt. Az ő eltartásuk családjukra hárult, vagy ha nem voltak ott rokonaik (például idős özvegyek vagy házaspárok), akkor a táborlakók közösségére. A rendőrségi felügyeletet az ún. K-örsök, vagyis az erre a feladatra felállított különleges egységek látták el. Ezek kezdetben a helyileg illetékes megyei rendőri szervek hatásköre alá tartoztak, 1953 elejétől viszont egységesen a Hajdú-Bihar megyei rendőrség illetősége alá kerültek.

A Belügyminisztérium 1950. július 13-án kelt határozata szerint a deportáltak megnevezésére a „telepes”, „telepített” kifejezést kellett használni: „Ez a megjelölés jogszabályainkban eddig ismeretlen és sem ez, sem pedig az alkalmazott szabadságkorlátozások nem tartoznak sem a rendőrhatósági felügyelet, sem az internálás, sem a kitiltás fogalma alá. A gyakorlatban kialakult szokás alapján a kitelepített személyek megjelölésére a »telepes « elnevezés vált használatossá. A telepesek tehát olyan személyek, akik ellenséges cselekedeteik folytatásának megakadályozása végett lakóhelyükröl családjukkal együtt ki lettek tiltva, és egyes állami gazdaságok területén, kényszertartózkodásra lettek kötelezve. Tekintettel arra, hogy személyiségük és magatartásuk nagyobb veszélyt jelent a társadalomra, államunk belső és külső biztonságára, mint a rendőri felügyelet alá helyezett vagy kitiltott személyeké, így szükségessé vált velük szemben a

13 Térkép: Dr. Hajdú Lajos. Forrás: Saád József: Hortobágy. A magyar Gulág. In: Rubicon 2010/6. 7.o.

14 A 12 tábor létesítésük sorrendjében: 1950: Lenintanya, Kónya, Árkus, Borzas-Mihályhalma, Kócspuszta, Erzsébet-tanya, Kormópuszta; 1951: Tedej, Elep, Ebes; 1952: Lászlómajor, Borsós I.-II.

15 Bank-Gyarmati-Palasik, 2012: 49-51. 


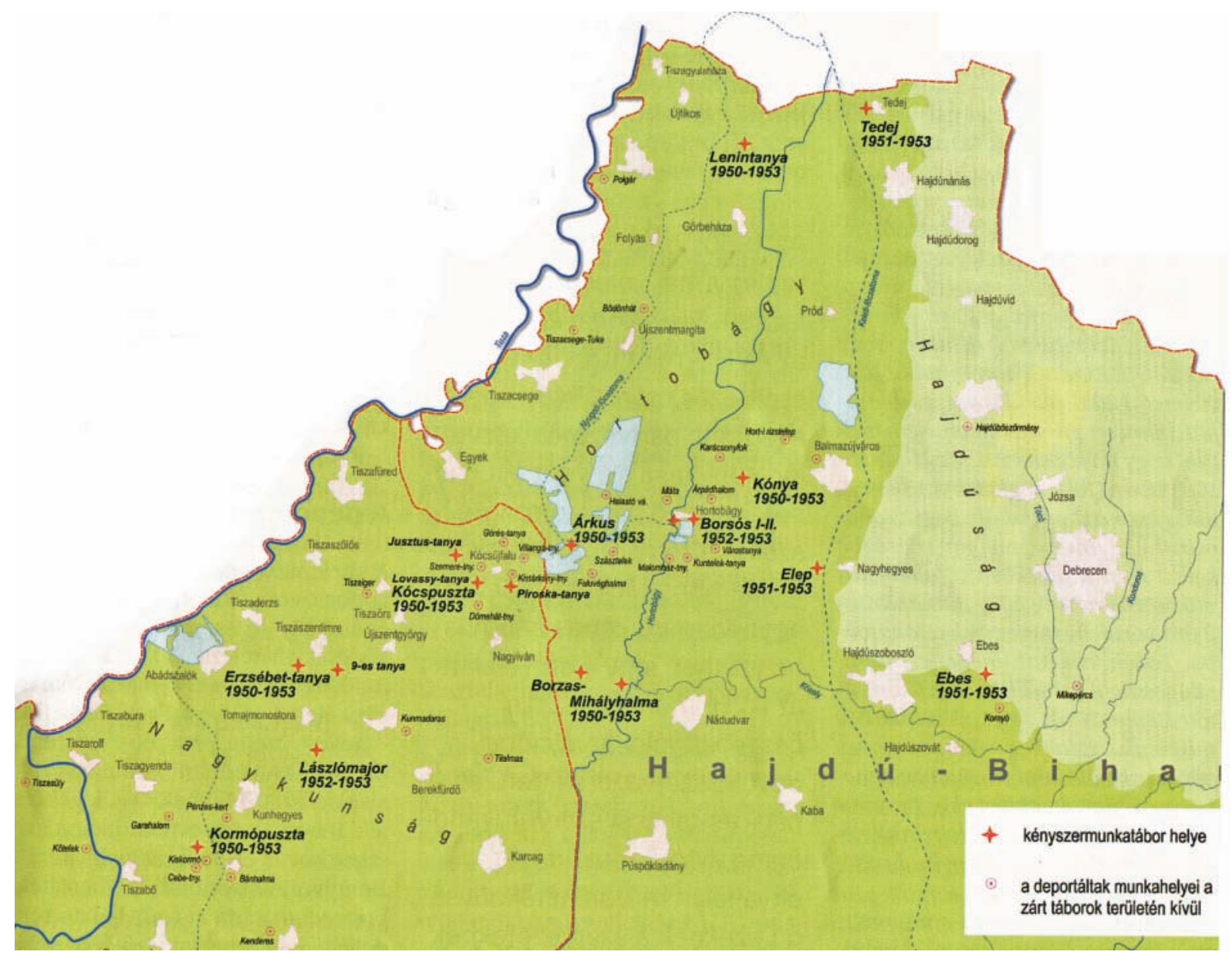

1. ábra. A deportált családok zárt kényszermunkatáborai a Hortobágyon, a Nagykunságban és a Hajdúságban, 1950-1953. Térkép: Dr. Hajdú Lajos.

fent leírt szigorúbb szabadságkorlátozó intézkedések alkalmazása."16 A telepes státusa tehát nem büntetőjogi kategória, a velük kapcsolatos intézkedések nem hivatkoztak jogszabályra, a kitelepítési határozatban sem esik szó róla. „Jogszabályok hiányában, az indoklás szerint, az »ellenséges cselekedetek« folytatásának megakadályozása volt a családok munkatáborba hurcolásának célja." ${ }^{17}$

\section{A nagyatádi kitelepítés}

Somogy megye déli részén ötvenkét település esett a határsávba, amelyeket 1950-től kezdődően a

16 Hantó, 2006: 33.; Saád, 2010: 6.

17 Hantó, 2006: 33. Saád József így összegzi e témát: „A »telepesek« megjelölés [...] a helyi folklór képződménye. Az állami gazdaságok telepein, föként állattartó telepeken egymásra zsúfolt alja nép megjelölésére szolgált, akiknek a gazdaság dolgozóitól - amennyire lehetett - elkülönített »telepesbrigádokban« kellett dolgozniuk. A telepekről hajtották ki őket munkára, s a telepekre tértek nap min nap vissza, rendőri kísérettel. Mások voltak, mint a kulákházakba beköltöztetett, budapesti kitelepítettek. Maguk az érintettek »beutalásukat« inkább deportálásnak, s a telepet, ahol őrizetesek lettek, internálótábornak nevezik. A hospes- és pionír-asszociációkat, és az alávetettség megalázó emlékét keltő telepes megjelölést ma is cinikusnak és bántónak tartják." Saád, 2005: 321. deportálási hullámok mindegyike érintett. ${ }^{18}$ Nagyatád a határsávba átnyúló járás székhelye volt, és 1948-tól kezdődően több, az új politikai rendnek megfelelően átszervezett közigazgatási és rendészeti intézményt költöztettek ide. A déli határ közelsége miatt pedig határőr laktanyát és további katonai egységeket telepítettek a községbe. Ezek a tényezők befolyásolták az itt lezajlott kitelepítéseket.

Nagyatádra 1952. május 28-áról 29-ére virradó éjszaka sújtottak le az Államvédelmi Hatóság határőrökkel megerősített egységei, és mintegy 71 személyt, 26 családot deportáltak a hortobágyi Elepen (2. ábra) müködő kényszermunkatáborba. Somogyból akkor összesen

18 Az 52 község: Babócsa, Bakháza, Barcs, Bélavár, Berzence, Bolhás, Bolhó, Csokonyavisonta, Csurgó, Csurgónagymarton, Darány, Drávagárdony, Drávaszentes, Drávatamási, Görgeteg, Gyékényes, Háromfa, Heresznye, Homokszentgyörgy, Iharos, Iharosberény, Inke, Istvándi, Kálmáncsa, Kastélyosdombó, Komlósd, Lad, Lakócsa, Nagyatád, Örtilos, Péterhida, Porrog, Porrogszentkirály, Porrogszentpál, Potony, Rinyaszentkirály, Rinyaújlak, Rinyaújnép, Somogyaracs, Somogybükkösd, Somogycsicsó, Somogyszob, Somogytarnóca, Somogyudvarhely, Szenta, Szentborbás, Szulok, Tarany, Tótújfalu, Vízvár, Zádor (1950-től Baranyához), Zákány. Közülük hatot (dőlt betűvel szedve) nem érintett a kitelepítés, némely községet viszont többször is (pl. Csokonyavisonta, Nagyatád, Tarany, Lakócsa). 


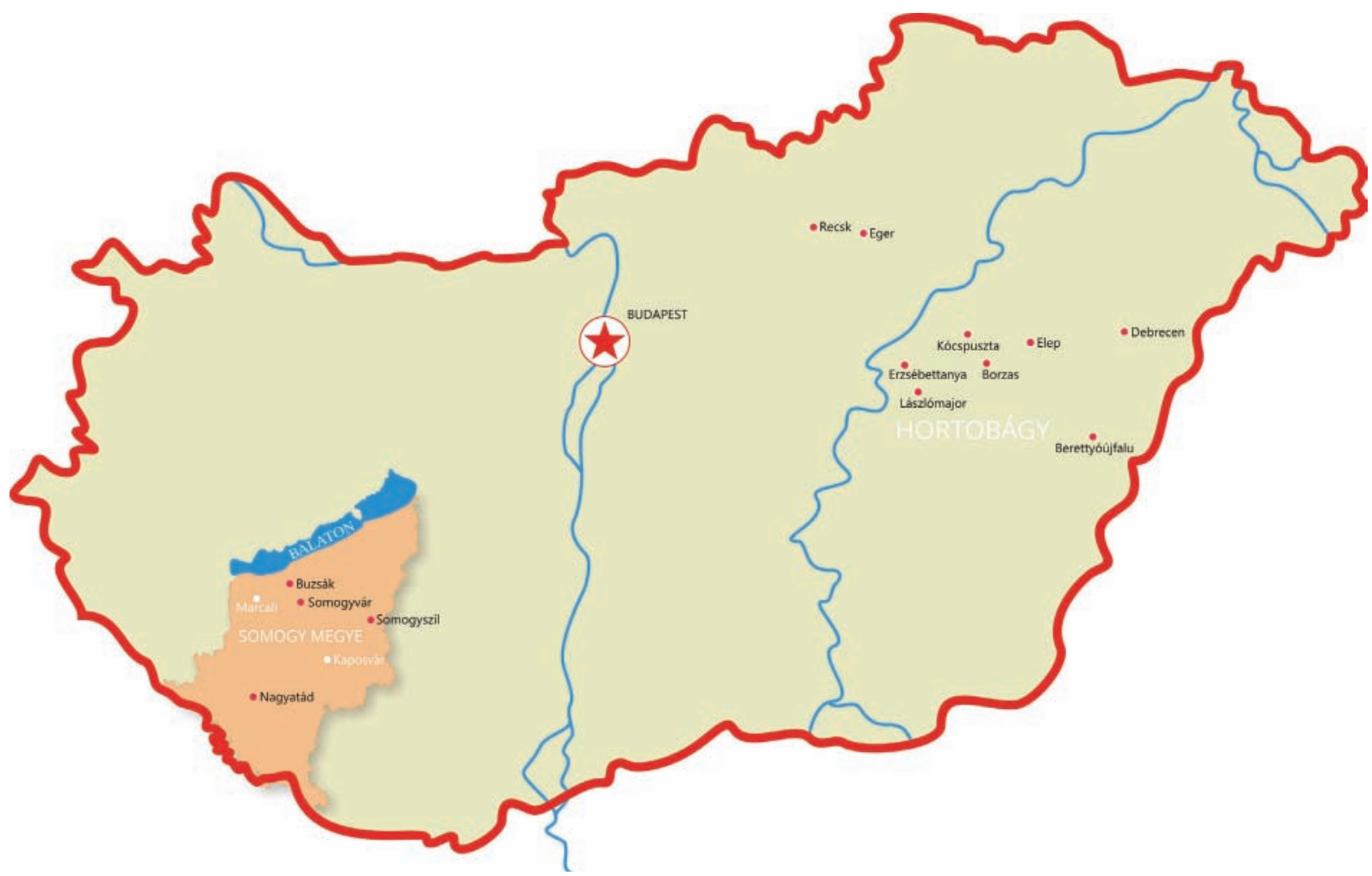

2. ábra. Nagyatád - Elep. A térképen az 1952. októberi kitelepités helyszínei is láthatók. Térkép: Huszár Endre

512 embert. ${ }^{19}$ Az alábbiakban a Veress-levelekben és a visszaemlékezésekben egyaránt hangsúlyosan felmerülő témakörök mentén kísérem végig a történteket.

\section{Az elhurcolás}

A beszélgetésünk idején 95 éves interjúalanyom 1952-ben 29 éves fiatalasszony volt, akit férjével, két - 6 és 8 éves - gyermekükkel, és idős apósával együtt deportáltak. Ő így emlékezett vissza az elhurcolás éjszakájára:

„Hát éjjel tíz órakor jöttek, fölköltöttek, mondták, hogy fél óra. Na, most félóra alatt az ember szedjen össze mindent, öltöztesse fel a két gyereket. Föl is kell költeni, nehogy frász jöjjön rájuk. Akkor mondtam nekik, hogy elmegyünk máshová lakni, jöttek értünk a katona bácsik. Gyorsan szedjetek, öltözködjetek, szedjétek a ruhátokat, meg a játékot, amit akartok. És akkor elkezdtük összepakolni. Nagy szerencsénk volt, mert volt egy nagy láda a padláson. Valamikor a cérnagyár árusította ki, és abba mindent beledobáltunk. [...] Na, most ez érdekes: a kiskatonák elég rendesek voltak. Mondták, hogy lehet, az én szüleimet is viszik, én nem tehetek róla, engem ide küldtek. [...] Akkor mondom, egy szem kenyerem nincs." [Ekkor a katonák megengedték neki, hogy bekopogjon a szomszédba, és a szomszédok szóltak a szülőknek, hogy viszik őket - ők hoztak kenyeret és tejet]. Hát, amit összekapkodott az

19 Saád (szerk.), 2005: 29. 74. lábjegyzet. ember félóra alatt! Hát, volt olyan a Hortobágyon, akinek egy tányérja nem volt. [...] Akkor az volt a szerencsém, hogy Taranyból egy évvel előbb már vittek. És akkor mesélték, hogy nem vittek vizet, és egész úton, egész a Hortobágyig nem volt vizük. Erre nekünk volt sok, mert hordtuk az ártéziról [artézi kútról) az ivóvizet. Én három vagy négy kannát gyorsan megtöltöttem vízzel. Nekünk volt vizünk."20

Dukai Róbertné Solymosi Mária 1952-ben 14 éves volt, éppen az utolsó heteket töltötte az általános iskolában. Ő így idézte fel az elhurcolás éjszakáját:

„... nyolcadikos voltam, és Keszthelyen voltunk osztálykiránduláson, és éjjel fél egyes vonattal jöttünk haza, és alig hogy lefeküdtem, aludtam, és jöttek, zörögtek, és kék ávósok voltak. Nem tudom, hányan, de többen voltak, öten-hatan biztos voltak, de az is lehet, hogy többen, nem tudom, és akkor, mikor az apu kinyitotta az elöszobaajtót, akkor mondta, hogy pakoljanak össze félóra alatt, amit tudnak, gyorsan, mert ki lesznek telepítve Hortobágyra."21

20 Interjú Horváth Istvánnéval; Az idős asszonnyal való beszélgetés azért is volt külön értékes, mert az interjúk készítésének idején (20152018) már nagyon kevés egykori kitelepítettel lehetett találkozni, aki felnőttként élte át az eseményeket. Leginkább - az idő előrehaladása miatt - már csak azok érhetők el, akik kamaszként vagy még egészen kisgyermekként szenvedték el a történteket. Az ő visszaemlékezéseik ugyanolyan értékesek, ám gyermekként természetesen másként láttak, éltek meg dolgokat, mint a minden felelősséget vállalni kénytelen szüleik generációja. Nagyon érdekes ebből a szempontból Kunt Gergely tanulmánya, amely egy kamaszlány naplójának elemzésén keresztül mutatja be a kitelepítést. Kunt, 2015.

21 Dukai Róbertnével készített interjú részlete, 2018.11.21. 
A nagyatádi kitelepítés a korábbi években már bejáratott rendszer szerint zajlott: az Államvédelmi Hatóság (ÁVH) egységei éjjel 1-2 óra körül rajtaütésszerüen megjelentek a községben, körülzárták, és megkezdték a kijelölt személyek, családok összegyűjtését. A kitelepítendők listáit az ellenséges (reakciós, kulák stb.) elemekröl készült többféle lista - tanácsi, üzemi, pártszervezeti, rendőri, államvédelmi - alapján az ÁVH-n belül véglegesítették. Innen a megyei rendőrkapitánysághoz kerültek, ezektől indítványként a belügyminisztériumhoz. Ott állították ki a személyre szóló véghatározatokat, amiket a kitelepítést végrehajtók megkaptak, és ami alapján begyűjtötték az embereket. ${ }^{22}$ Mindegyik kijelölt ház elé odaállt egy teherautó, és 6-7 „kék ávós” (vagyis karhatalmista), ill. rendőr nyomult be a házba. A felriasztott családra fegyvert fogtak, felolvasták, és a családfővel aláíratták a véghatározatot, majd - az intézkedő tiszt jóindulatától függően - egy-két órát adtak a pakolásra. Mint az idézetből is látható, a családok nem kaptak előzetes értesítést arról, mi vár rájuk: teljesen felkészületlenül, végletesen kiszolgáltatott helyzetben kellett csomagolniuk, elindulniuk, úgy, hogy nem tudták, hová és mennyi időre kell elmenniük (és hazatérhetnek-e még valaha). A kitelepített családok élettörténetének fontos fordulópontja volt ez az éjszaka, és az elkövetkező időszak.

A véghatározat az 1939-es honvédelmi törvény egyik végrehajtási rendeletére hivatkozott. Rendelkezett a családfő és a vele egy háztartásban élő családtagok „kitiltásáról” és „kényszertartózkodási helyre” távozásáról. Indoklása szerint „nevezett eddigi lakóhelyéről való kiutasítása és új lakóhelyének elfoglalása közérdekből szükségessé vált". A kényszertartózkodás helyét - nemegyszer hibásan - ugyan megjelölték, az időtartamát azonban nem. Fellebbezésre - egy 1929es közigazgatás-rendezési törvényre hivatkozva - nem adtak lehetőséget. Az egész családot érintő kitiltást tehát bünvádemelés vagy bírósági eljárás és ítélet nélkül, egyszerü rendészeti határozattal hajtották végre.

A véghatározatok személyre szólóan voltak kiállítva, fölsorolták rajta az összes, az adott háztartásban élő családtagot. A nevek gyakran hibásak voltak, így többször előfordult, hogy nem családtagot is elvittek, ha - tévesen - szerepelt a véghatározaton. De olyan is megesett, hogy valaki nem szerepelt ugyan rajta, de éppen ott tartózkodott a házban (mint albérlő vagy vendég), így őt is elvitték. Sőt, olyan is volt - mint a Veress család esetében -, hogy nem volt véghatározat: ott helyben állították ki az üres nyomtatványt, úgy, hogy még az illető nevét is ott kérdezték meg. Az elsődleges szempont a ház, a lakás kiürítése volt. Megtörtént olyan eset is, hogy a családfő nem volt hajlandó aláírni a kitelepítési végzést, ám ez semmiben nem befolyásolta az elhurcolást:

„És írja alá a papirt. És az édesapám azt mondta, hogy nem írom alá. És mondta a kék ávós, hogy ha nem írja alá, akkor beleeresztek egy sorozatot. Már hogy agyonlövi édesapámat. És azt mondta édes-

22 E listákat - eddig még legalábbis - sehol nem találtam. A korabeli tanácsi jegyzőkönyvekben pedig utalás sincs a történtekre. apám, akkor se írom alá. Úgyhogy nem lőtték agyon édesapámat, fölpakoltak az autóra, akkor is elvittek bennünket. Tehát teljesen mindegy. És az én apám az ilyenbe borzasztó konok volt, önfejü volt... Amire büszke vagyok, még így is, ilyen áron is..."23

A kiürített házat lepecsételték, további rendelkezésig „népi őrt” bíztak meg a felügyeletével. Az ingatlanok közintézmények (határőrség, párt- és tanácsi szervezetek, népbolt, tszcs stb.), a gazdasági felszerelés és az állatállomány pedig, a földdel együtt többnyire az alakuló termelőszövetkezetek tulajdonába került. Az ingóságokat, amelyekre a közintézmények, különböző funkcionáriusok nem tartottak igényt - helyenként leltározás után - általában elárverezték, szétosztották. ${ }^{24}$ A kitelepítés tehát teljes vagyonelkobzással járt együtt.

\section{Az út}

A felpakolt teherautók a hajnali, reggeli órákban indultak a házaktól a gyűjtőhelyre, a nagyatádi állomásra, ahol megtörtént a bevagonírozás. Egy-egy vagonba általában két vagy három családot helyeztek el, minden holmijukkal (olykor állatokkal) együtt. A vagonokat lezárták. Az elbeszélések szerint addigra már sok atádi kint volt az állomáson, akiket a katonák tartottak távol a vagonoktól. Május 29-én reggel tájban indult el a szerelvény (Somogyszobon „összevissza löködték”, valószínűleg máshonnan érkezett vagonokat kapcsolták még hozzá), és 31-én hajnalra, két nap alatt értek a célállomásra. A visszaemlékezésekben a megérkezéssel kapcsolatban többször szóba kerül a megkönnyebbülés érzése: Magyarországon vannak. Kelet felé tartva ugyanis végig attól féltek, hogy a végállomás Szibéria lesz, ahonnan nincs visszatérés.

A vagonokból többen próbáltak hírt adni magukról családjuknak, ismerősöknek. Mesélték, hogy Somogyszobon a vagonokból cetliket dobáltak ki, a címzett mellett csak annyit ráírva: „Hortobágyra visznek". A cédulák közül több is célba ért. Egy vagonból kidobott levél fennmaradt a Veress-hagyatékban is (3. ábra): ${ }^{25}$ „Kérem, a jószívü megtaláló adja fel [a megadott] címre." Ebben olvashatók az alábbi sorok:

„Édeseink! Valahol Füzesabonyon túl járunk. Nehéz megállapítani, mert nem áll meg velünk a vonat, úgy száguld, mint egy gyors. Ha Ti is így járnátok, egykét tapasztalat: Bimbit hozzatok, mert ritkán nyilik a vagon, Somogyszobon nyílt ki utoljára. Ruganyos matracot, esetleg az egész piros rökamiét hozzátok, mert csak fekve lehet kibírni a rázást."

Az egész levél praktikus, gyöngéd tanácsokkal van tele arra az esetre, ha a gyermekek a nagymamával együtt a szülők sorsára jutnának. Úgy tủnt akkor, hogy

23 Részlet Dukai Róbertnével készített interjúból.

24 Veress Péter mesélte, hogy szülei könyvtárát lakóházuk kapualjában árverezték el, darabonként egy forintért. Neki akkor összesen két forintja volt, abból vásárolt meg két kislexikont, amelyet édesanyja gyakran forgatott és jegyzeteivel látott el. A könyvtárat végül az iskola - ahol Veress Dezsőné tanított - kiigényelte magának, és évekkel később visszaadták a családnak.

25 A levelekböl kiderül, hogy hat vagy hét levelet is kidobott Veressné, de végül csak ez az egy ért célba. 

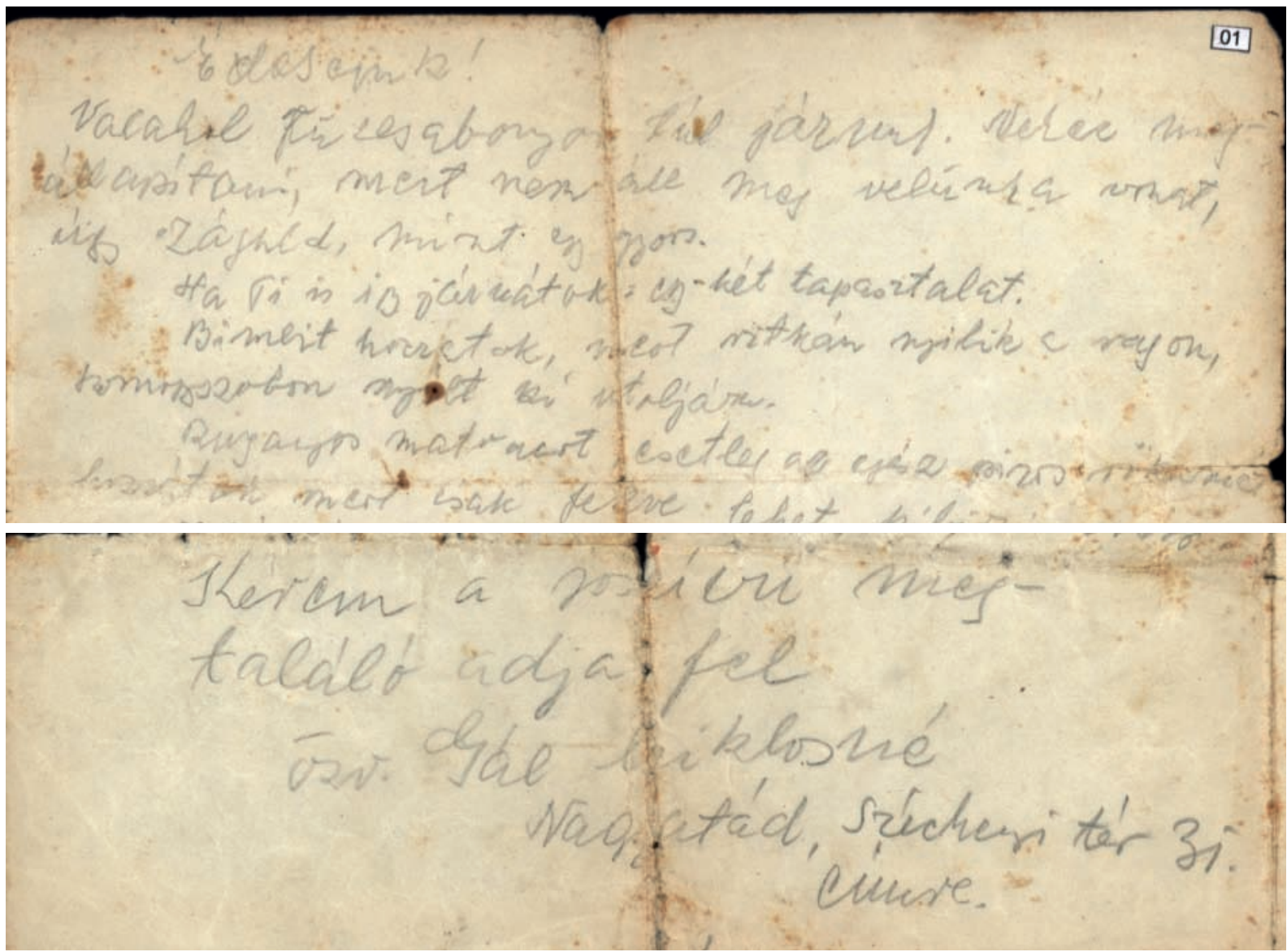

3. ábra. Részletek Veress Dezsőné vagonból kidobott leveléböl, 1952. május 29-30.

ezt ők sem kerülhetik majd el. (S valóban, az októberi kitelepítés folyamán deportálták őket Somogyvárra.)

Egy visszaemlékezésben az alábbiakat olvashatjuk az útról:26

„A szüleimtöl tudom, hogy hosszú, több napos volt az út az Alföldig a marhavagonokban, és senki nem tudta, hova visznek minket. Így ők Szibériára gondoltak, és végül is örültek, hogy magyar földön maradhattunk. Néhány gazdának megengedték az ÁVO-sok, hogy zöldséget, élelmet, szerszámokat, sőt még tehenet is hozzon magával a vagonba, amit persze a táborba érkezéskor rögtön elvettek. Mindig hálás leszek a sorstársaknak, akik egy ilyen tehén tejéből juttattak

26 Selmeczy Miklós 1950-ben született, és a kitelepítés idején mindössze három hónapos volt (nővére ötéves), amikor Pécsről Polgár Lenin-tanyára telepítették ki őket. Visszaemlékezését (2019-ben) szülei elbeszélésére alapozva írta le, de saját emlékei is maradtak erről az időszakról. Édesapja, Selmeczy Miklós hivatásos katonatiszt volt 1945-ig, 1947-ben tért vissza a szovjet hadifogságból. Édesanyja, gróf Somssich Mariteréz Kivadáron (Nagyatád melletti pusztán) született, a kivadári birtokos, gróf Somssich Géza és Szőgyény-Marich Mária gyermekeként. Kivadáron az 1940-es évek végére csupán a szovjet hadifogságból hazatért Somssich Zsigmond és idős édesanyjuk maradt. A birtok államosítása után Nagyatádra költöztek, innen telepítették ki őket Elepre 1952 májusában. Pár hónappal később kérvényezték, hogy a családtagok egy helyre kerülhessenek, így Somssich Zsigmondot és édesanyját átszállították Lenin-tanyára. nekünk is, mert Édesanyámnak az éhezéstől elment az anyateje, és így egy rab tehén tejével én is túléltem az utat. Édesanyám mesélte, hogy miután a táborban elkobozták a tehenet, egy kedves néni még hozott nekem egy utolsó üveggel, amit azonban a rendör földhöz vágott, mert mint mondta, a gyereknek erre már nem lesz szüksége, hisz úgyis itt zsírozza majd meg a földet. De, hála a magyar paraszti tapasztalatnak, a sorstársaink megtanították Édesanyámat a bab héját levenni, így aztán a fött babpüré lett a táplálkozásom nagy része. Az biztos, hogy a bableves lett egész életemben a kedvenc ételem."

A célállomáson a „szállítmányokat” a járási rendőrkapitányságok vették át az ÁVH-tól. A kivagonírozás lebonyolítását rendőrök irányították az állami gazdaság embereinek a segítségével. A felnőtteket többnyire gyalogmenetben, az öregeket, gyerekeket vontatókon, fogatokon szállították kijelölt telephelyükre. Veress Dezsőné levelében így ír a megérkezésről, és az őket fogadó ismeretlen tájról, amelyre - a szörnyü helyzet ellenére is - rácsodálkozik:

„Hosszú vaggon-utazás után szombat hajnali 3-kor értünk ide. Balmazújváros utáni állomás Hortobágy, ott tettek ki délután, estig üldögéltünk a csomagokon, majd vontatóval $16 \mathrm{~km}$-t vittek befelé a puszta belsejébe. Érdekes ez a Hortobágy. Végeláthatatlan pusz- 
taság és 1-2-3-5 km távolságra elszórva tanyák vannak, körülötte 1-2 akácfa, aztán ismét puszta, puszta, sehol egy fa, sehol egy ház, se domb, se patak."27

\section{Kiket vittek el Nagyatádról?}

A határsávból történő kitelepítés az „osztályidegeneket és ellenséges elemeket” érintette, vagyis a polgárságot, a korábbi politikai és államigazgatási elit tagjait, a falvak tulajdonos parasztságát és családjaikat. ${ }^{28}$ A kitelepített nagyatádiakat a családfő származása, foglalkozása, illetve az akkori ellenség-kategóriák szerint az alábbiak szerint sorolhatjuk be:

\begin{tabular}{|l|l|}
\hline volt horthysta katonatiszt & 4 \\
\hline volt csendőr & 4 \\
\hline „kulák” & 3 \\
\hline ügyvéd & 3 \\
\hline volt arisztokrata & 2 \\
\hline volt nyilas & 1 \\
\hline volt Szociáldemokrata Párttag & 1 \\
\hline kiskereskedő, kisiparos & 4 \\
\hline a meglévő adatokból nem kideríthető & kb. 10 \\
\hline $\begin{array}{l}\text { hozzátartozók (feleség, anya, anyós, } \\
\text { gyerekek) }\end{array}$ & 32 \\
\hline
\end{tabular}

A nagyatádiak között a legidősebb 84 éves volt (férfi), és három 70 év feletti asszonyt is elvittek. A legfiatalabb egy kétéves kislány, akinek egyik testvére 4, a másik 12 éves volt akkor. Vittek el egyedülálló férfiakat, sőt asszonyt is, házaspárokat, többször egyikük idős anyósával vagy apósával együtt, és vittek két-három gyermekes családokat is (6 családot, összesen 26 fővel). Összesen mintegy 22 családot hurcoltak el, de egészen pontos adatok, létszámok - sajnos - nem kideríthetőek. ${ }^{29}$

\section{A célállomás: ELEP ${ }^{30}$}

Az elepi tanyavilágra épült állami gazdaságban 1951 tavaszán hozták létre a tábort. Amikor a nagyatádiak a többi somogyival együtt megérkeztek ide, a tábor létszáma 498 fő volt, ami az új érkezőkkel együtt 982 före emelkedett. A „telepes”-nek nevezett rabok a rendőrörs és az elepi állami gazdaság központja körül, ill. a környező tanyákon éltek, két-három kilométeres körzetben. A kényszermunkatábort őrző rendőrök

27 Veressné 2., „fekete levele” (azaz még nem engedéllyel küldött), keltezés nélkül.

28 Hantó, 2006: 36.

29 Az adatokat a visszaemlékezések, a levelek, ill. a Hajdú-Bihar Megyei Levéltár honlapján található korabeli névsor alapján állítottam össze: http://gulag.hbml.hu/adatbazisok/elepi-kitelepitettek

30 Elep ma Nagyhegyes község településrésze, Balmazújvárostól 10, Debrecentöl 25 km-re található.
(K-örs) biztonsági okokból azon voltak, hogy minél több családot egy helyre zsúfoljanak, így esetenként egyegy tanya létszáma meghaladta a száz föt. A szállásra alkalmasabb istállókon, hodályokon túl a fészerek, a baromfi- és disznóólak is benépesültek. Szétszórtsága, tanyás jellege miatt az elepi tábor kijelölése és őrzése végig körülményes és nehezen megoldható volt, az őrsparancsnokság nem tudta egy pontból szemmel tartani a tábor egészét. Az őrség létszáma az első évben egy parancsnok és nyolc beosztott volt, amit 1952 májusában 24 före emeltek. ${ }^{31}$ A kitelepítettektől megérkezésükkor, az első - és aztán naponta ismétlődő - sorakozón elvették az irataikat, a magukkal hozott értéktárgyakat, a veszélyesnek minősülő anyagokat, eszközöket (pl. szeszes ital, fényképezőgép, gyógyszer, kerékpár, írógép). A magukkal hozott jószágokat is elkobozták, és átadták az állami gazdaságnak. Pár napon belül tehát kétszer is kifosztották őket. A deportáltak ily módon telepessé degradálódtak, és bizonytalan időre kihullottak az állampolgárok köréböl - törvényen kívülivé váltak. ${ }^{32}$

Egy levélrészlet arról, hogyan nézett ki a telepesek elhelyezkedése:

„A tanyák 1 lakóházból és 2-3 melléképületböl állnak. Kulákok laktak benne azelött. A mi tanyánk egy 3 szoba, előszoba, konyhás lakásnak épült, de nem készült el egészen. Az oldalai megvannak és cseréppel be van fedve. A közfalak részben vannak meg, plafon nincs, ajtófélfák, ablaktokok nincsenek. Van egy cselédház, 2 szoba-konyhával, mindhármat lakószobának használják, van egy istálló és egy ól. 96-an lakunk bennük. [...] Az ablakhelyek be vannak csinálva téglával, az ajtóhely éjjel-nappal állandóan tárva. Minden tanyán rendőr-őr váltja egymást. Egyik tanyából a másikba nemigen járhatunk, azaz csak meghatározott tanyákba. Így nem nagyon tudjuk, hogy hol, kik és hányan vannak ismerösök. Az ör éjjel is végigjár párszor, ránk világít, aztán távozik."33

A legtöbben az istállókban, juhaklokban laktak, sőt volt olyan család, amelyiknek csak az egykori tyúkólban jutott hely.

„Hogy ott hogyan éltünk? Oda vittek, volt egy istálló. Az istálló két oldalán voltak a fekhelyek. Középen el lehetett menni. Most, az ágyak között csak úgy volt hely [...], hogy ahol nem volt ágy, egy családnak vaságy volt, az csak 70 centi volt, hát akkor így maradtak helyek. ${ }^{34}$ Különben akkor így rálépett az ember az ágyára. Akkor loptunk, az épület ugye vályogból volt, bevertük [a szeget], akkor loptunk rá deszkát. Voltak ott elhagyatott tanyák, akkor a gépállomásról hoz-

31 https://www.telepesek.hu/taborvilag_elep.html. letöltés: 2020. 05. 11. 32 Saád, 2005: 311-314.

33 Veress Dezsőné levele, keltezés nélkül [1952. június]

34 Egy-egy személynek kb. $80 \mathrm{~cm}$-es helyet jelöltek ki, amit azt jelentette, hogy az ágyak, a fekhelyek szorosan egymás mellett kellett legyenek, nem volt köztük közlekedő hely. Voltak azonban többen, akik nem vittek magukkal otthonról ágyat, ezért Elepen kaptak: házaspáronként egy darab, $70 \mathrm{~cm}$ széles vaságyat, ami két ember számára borzasztóan keskeny és kényelmetlen volt. Viszont, mive ezek keskenyebbek voltak, mint azok az ágyak, amiket otthonról vittek magukkal, maradt valamennyi hely mellettük, ahol lehetett úgy járni, hogy nem kellett rálépni az egymást érő fekhelyekre. 
tak, és akkor csinált az ember [polcot, fogast]. Akkor küldtek hazulról vállfát, a gerendába vertünk szöget, fölakasztottuk, amit föl lehetett, aztán lepedővel körülkerítettük. ${ }^{35}$ Hát volt, amikor sütöttem kalácsot, aztán a tepszit oda tettem az ágyra, letakartam, Pista [férje] meg belelépett. [Később] Egy 6×6 méteres szobába laktunk tízen [3 atádi család]. Úgyhogy összeért a lábunk, és épp hogy csak az ágyak között el lehetett menni. De legalább magunk laktunk."36

\section{Napirend, munka, kereset}

Az életvitel napi rutinja mindegyik táborban hasonló volt. Veress Dezsőné egyik levelében így írja le a nyári munka- és napirendet:

„A napirend kissé szokatlan és egyelöre nehéz. Reggel 1/2 4-kor ébresztő, 1/2 5-kor jelentkezés a „rendör-tanyán" (4-5 km), ott megkapjuk az utasítást a munkára, egy egész közeli tanyán megkapjuk a szerszámokat és indulunk párban, 3-as sorokban. Brigádokra vagyunk osztva, a brigádok csoportokra. A mi munkacsoportunk 8 személy, csupa nők, Dezsőé 12 személyből áll. Munkanapló van és minden csoport munkáját lemérik. Mi tegnap az én csoportommal 2246 négyszögölet kapáltunk meg, Dezsőék 3350-et. A munkahely néha messze van. Tegnap 8 km oda, 8 vissza volt az út. A munkaidő 12 óra, mely a reggeli $1 / 25$-ös szerszámosztástól kezdődik és a munkahelyen este 6-kor fejeződik be. Ott van 1-1 és 1/2 óra ebédszünet. A reggelit és az ebédet a munkahelyen kapjuk, a vacsorát itthon. A reggeli $1 / 2$ liter feketekávé, az ebéd 2 tál étel, a vacsora 1/2 I. feketekávé és hozzá mindig valami. A kenyeret magunk vesszük. "37

Tizennégy év felett mindenkinek dolgoznia kellett: „Öregnek, gyereknek, mindenkinek. Aki csak élni és mozogni tudott, aki nem volt beteg. Mindenkinek menni kellett."38 Nyáron a kapálás, gyomlálás és a betakarítás voltak a legnagyobb munkák. Az aratás kézi erővel történt: a gabonát a férfiak kaszálták, az asszonyok, fiatalok gyújtötték, kötötték marokba, a nagyobb gyerekek vízhordók voltak. Kézi erővel aratták a lent, a gyapotot, illetve - már ősszel - a rizst. Ez volt az egyik legmegterhelőbb munka, mert „térdig, térden felül ért az iszap. Mert az [a rizs] vízben, [...] iszapban terem meg, és lecsapolták a vizet, de ugye tiszta iszap, tiszta sár maradt, és abban voltunk és úgy szedtük a rizsát". ${ }^{39}$ Akkor már szeptember vége, október eleje volt, hideg, s emiatt a nők többsége súlyos betegségeket szedett össze.

A rabok normára dolgoztak, és annak teljesítése fejében kaptak fizetést. Ebből levonták az étkezés díját, a „táborfenntartási díj”-at (ez vajon mit jelenthetett?), és ezek után a legtöbbször nem, vagy alig maradt belőle egyébre (ruha pótlására, javítására, levélpapírra, bélyegre, csomagküldésre, szappanra, az élelmiszer kiegészítésére volt a legnagyobb szükség). Azok a családok voltak jobb helyzetben, amelyekben

\footnotetext{
35 Így próbálták a családok elkülöníteni magukat. Ennyi „privát szféra" jutott számukra a kitelepítés egész ideje alatt.

36 Részlet Horváth Istvánnéval készített interjúból.

37 Veress Dezsőné levele, keltezés nélkül [1952. június]

38 Részlet Dukai Róbertnével készített interjúból.

39 Uo.
}

többen is dolgozni tudtak, és nem kellett idősről vagy gyerekről gondoskodniuk. Azok viszont, akiknek egy vagy több gyermekre kellett keresni, a gyerekek miatt a feleség nem tudott munkát vállalni, vagy ahol munkaképtelen idős volt, nagyon nehéz helyzetben voltak, és gyakran az átlagnál is nagyobb nyomorban éltek.

Nyáron és ősszel mindenkinek volt munkája, ősz vége felé, télen azonban egyre nehezebben tudott a gazdaság munkát biztosítani minden munkavállaló számára. Aki tehette, próbált az állattartásban munkát találni, mert - bár nehéz volt, de - kiszámítható, hosszú távú, ráadásul az istállókban, az állatok mellett melegebb volt, mint a kinti munkák (kubikolás, favágás a Mátrában, cukorrépa kiszedése a hó alól) esetében. S az állatok mellett olykor volt lehetőség egy kis élelempótlásra is (titokban lefejt tej, az állatoknak adott kukoricadarából, néha hús is).

"[...] amikor ilyen nagyon hideg volt és megfáztunk, az istálló viszont nagyon jó meleg volt. [...] mindig azzal kezdtük a napot, hogy a trágyát kihordtuk, utána etettünk, itattunk meg ilyesmi. Na, most, amikor ennyire meg voltunk fázva, ugye, voltak kedvenc marháim nekem, amiket szerettem, meg elbeszélgettem velük, és amikor feküdtek, akkor odabújtam hozzájuk, hogy megmelegedjek egy kicsit. Azt úgy átöleltem, és úgy az elsö lábuknál, ahogy ugye így oldalt feküdtek, az első lába itt volt, és én itt becsúsztam a hasa alatt, és akkor átöleltem, és nem bántottak..." - emlékezett vissza az akkor 14 éves kislány, aki édesapjával és egy évvel idősebb nővérével együtt hatvan marhára viselt gondot. ${ }^{40}$

Veress Dezsőné levelének részlete jól illusztrálja, milyen volt a családok anyagi helyzete a táborban (ők, férjével együtt, mindketten dolgoztak és kerestek, tehát aránylag jobb helyzetben voltak):

„Dezsőnek most 50 üszője és 50 ökre van, felét kint legelteti, fele alól trágyáz. Jobb abból a szempontból, hogy csak 50 marha trágyáját kell cipelnie, de rosszabb, mert a kinn éjszakázók után most sokat kell szaladgálnia. Súlygyarapodás és szaporodás szerint fizetnek neki. A múlt hónapban csak 440 ft-ot keresett; levonták a kettőnk ebédjét, az egy hónapra $400 \mathrm{ft}$-ot, levontak $3 \%$ tábor fenntartási díjat és 20 ft. békekölcsöntt1 s így 1-2 ft-ot kapott kézhez csak. Az azelötti hónapban $700 \mathrm{ft}$-ot keresett, de akkor se kapott sokat kézhez, mert a téli koszttartozásokat vonták le. Az én keresetembő/ ${ }^{42}$ vesszük a reggeli és vacsora pótlékot, kenyeret, petróleumot, szappant stb.-t és abból küldözgetünk néha a gyerekeknek." (1953. május 20.)

40 Dukai Róbertnével készített interjú részlete.

41 A békekölcsön 1949-töl 1955-ig bevezetett sajátos megtakarítási forma volt. Azt jelentette, hogy az állam minden dolgozó állampolgártól elvárta, hogy évente legalább egyhavi fizetését békekölcsönbe fektesse, így segítve az államot „a békéért folyó küzdelemben”. A békekölcsönért nem kamat járt, hanem sorsoláson húzták ki a nyerteseket. Kötelező volt, és rendkívül népszerütlen az emberek körében, akik - mint látható - kényszermunkásként sem bújhattak ki a jegyzés alól. A kommunista hatalom végtelen cinizmusát tükrözi ez az eljárás.

42 Veress Dezsőné szeptembertől a telepes iskolában tanított, és mint tanító kapta fizetését, amelyet a telepes iskolába járó gyerekek szülei - és nem az állam vagy a gazdaság - adták össze. 
Ebben a helyzetben döntő jelentőségü volt a hazulról küldhető csomag. Általában havi egy vagy két csomagot kaphattak a kitelepítettek. Ezekből igyekeztek pótolni élelmüket, ill. ruházatukat, gyógyszereiket. A csomag a táborok müködésének (eltartásának) nélkülözhetetlen tényezője lett, az otthon maradottak nem csak a szükebb rokonság - élelmiszerküldeményei mintegy „belekalkulálódtak” a táborélet rendjébe. Így a büntetés legföbb eszköze volt, ha valakit eltiltottak a csomagtól. Ez a helyzet akár a kiéheztetéshez közeli, katasztrofális állapotokat okozhatott, ezért tartósan sehol sem alkalmazták. ${ }^{43}$

A csomagokat - ugyanúgy, mint a leveleket - a helybeli rendőrőrs cenzúrázta, azaz előzetesen átvizsgálták a tartalmukat, aztán az élelmiszer vagy a címzetthez került, vagy a közös konyhára, esetleg az őrsön maradt. Előfordult az is, hogy hiányosan, felbontva, megdézsmálva kapták meg a címzettek, ahogy Veressné egyik levelében is olvasható: „Tegnap megjött a csomag. OIdalt egy arasznyi fel volt bontva és hiányzott a Jutka lapja szerinti leltárból a gríz, a cukor, egy doboz keksz, diós beigli és füzetek. Kérlek, a csomag aljára tegyétek ezentúl az értékest és kiemelhetőt, felülre krumplit és ilyeneket." (1952. október 14.)

\section{Az iskola}

Az iskoláskorú gyermekek felügyeletét és tanítását táboronként eltérő módon oldották meg. Az elepi táborban élő csaknem ezer ember között sok 14 év alatti iskoláskorú gyermek is volt, akikkel 1952 tavaszáig nem sokat törődtek. A somogyiak között azonban több pedagógus is volt, akik összefogtak a rendszeres tanítás érdekében, és kijárták, hogy iskolát alakítsanak ki a táborban. A kijelölt épületbe hoztak padokat, két táblát és egy vaskályhát. Sikerült - sok esetben az otthoni kollégák segítsége révén - tankönyveket, térképet, oktatásmódszertani anyagokat beszerezni, és megkezdődött a rendszeres tanítás. Az egyik tanító Veress Dezsőné volt, akinek a leveleiből így sok részletet megtudhatunk a kényszermunkatáborban működő iskoláról.

A tanítás osztatlan rendszerben folyt: a 31 alsó tagozatos kisdiákot Veressné kapta, ők délelőtt jártak az iskolába. A felső tagozatban 50 gyermek tanult, dr. Albert Józsefné (a csurgói járásbíró felesége) és egy henészi tanárnő tanították őket (az ő neve sajnos nem ismert). A tanítók fizetését a tábor közössége adta öszsze. Veressné így írt 1953. január eleji levelében egy volt nagyatádi kolléganőjének, aki sokat segített a tananyagok beszerzésében:

„Legelöször is az iskoláról írok. Tankönyvekért annak idején voltam Debrecenben s beszéltem a járási és a megyei tanács oktatási osztályával. Úgy vélem, hogy ennek eredménye, hogy kaptunk könyveket, nevelöi példányokat, kézi térképeket, 24 padot - csőbútorost -, íróasztalt - vadonatúj és ragyogót -, nyomtatványokat, osztálykönyveket stb.-t. Most az egyik osztályunk

43 Saád, 2010: 18 már egész elegáns. A felső tagozat tanul benne. Az én osztályom még a régi, az asztal, szék, sámlik, térképek, tábla mind „privát” tulajdon, a Ti jóvoltotokból. De prímán megvagyunk, jó kis osztály, jó anyag. Tüzelőt is kapok egyelöre a gazdaságtól, az édes, kifagyott kis csemeték meleg iskolába jönnek."

Egy másik levél megható részlete a nehéz körülményekre is rávilágít:

„»Szereztünk« fát, de a nagy tanteremben kell most lennem és az kifüthetetlen ilyen tüzelövel. Tegnap a „Tél gondjait” írták dolgozatba téli kabátban, sapkával a fejükön. Ma egyik-másik dolgozatot megkönnyeztem. Bár látnád! Édesek. Tegnap kis iskolai Márc. 15. ünnepélyt tartottam velük. Csillogott a szemük, mikor az „ünnepi beszédet” tartottam nekik. Minden szavamat értették. Okosak, jó tanulók, melegszívüek." (1953. március 14.)

Hatalmas eredmény volt, hogy a gyerekek hivatalos iskolai bizonyítványt (4. ábra) kaptak év végén, amit a kitelepítés után minden iskolában elfogadtak: ${ }^{44}$,Kiosztottuk a bizonyítványokat és a kitünök és jelesek jutalmat is kaptak, 5 Ft-t fejenkint, ami $150 \mathrm{Ft}$-t tett ki, s a közösség viselte. Boldogok voltak szegénykék a pénzükkel! Nekem 12 kitünőm és jelesem volt összesen." - újságolta boldogan Veressné egy 1953. júniusi levelében. ${ }^{45}$

\section{Ünnepek}

A rabságban töltött idő legkegyetlenebb, lelkileg legmeggyötrőbb időszakát talán az ünnepek jelentették. Ilyenkor még erősebben tört fel a honvágy, az otthon, a rokonok, a szabad élet iránti vágyakozás a kényszermunkatáborban élőkben. A levelekben és valamennyi visszaemlékezésben írtak, meséltek erről. Veress Dezsőné (akinek a tábor „kultúrfelelősi” szerepét is el kellett látnia), így számolt be az elepi karácsonyról (5. ábra) gyerekeinek:

„24-én este viszont Annuska gyönyörü kis ezüstfenyőjét díszítettük fel és meggyújtottuk rajta a gyertyákat [...] és kivittük a ház elé a sötét estébe. Guszti „beharangozott”, azaz megverte a munkára hívó „gongot”, ami egy nagy vasdarab, erre mind kigyült a nép, szokáshoz híven a ház elé, egy henészi kisfiú tartotta a karácsonyfát és elénekeltük a karácsonyi énekeket. Aztán Guszti messzeszálló hangon köszöntötte kis beszédben a tanya népét és békés ünnepeket kívánt. Utána bejöttünk, megterítettünk, oda raktuk az ajándékainkat az asztalra, meggyújtott gyertyáknál imádkoztunk, sírdogáltunk, vacsoráztunk, aztán hamar lefeküdtünk, imádsággal vártam meg az éjféli mise idejét és ábrándoztam az elmúlt évekről, amikor kitartó konoksággal jártatok a rorátékra, aztán az elmúlt Karácsonyok szép éjféli miséire, amikor az atádi templom-

44 A bizonyítványokat a „szabadok” területileg illetékes körzeti iskoláiban állították ki, az elepi gyerekekét a nagyhegyesi iskolában.

$45 \mathrm{Az}$ iskoláról és annak jelentőségéről Novák István csurgói kitelepítettekről szóló könyvében is megemlékezik, az egykori kitelepítettek visszaemlékezéseire alapozva (sajnos a neveket illetöen sok az elírás, pontatlanság). Novák, 2014: 63. Továbbá: Saád, 2010: 19. 


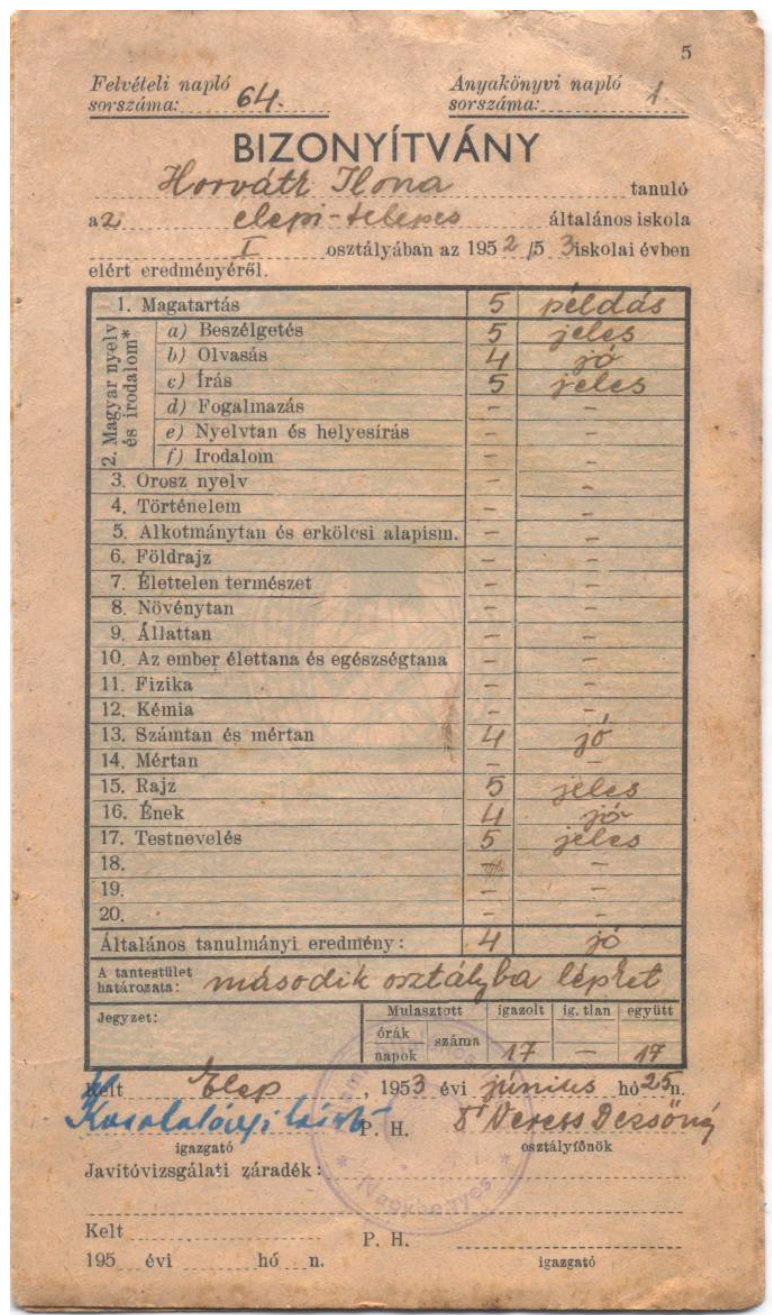

4. ábra. Az elepi iskolában kiadott bizonyítvány egy lapja.

ban Glóriánál kigyulladt minden ragyogó villanykörte. Oh, de szép volt! Messze elmaradt mögöttünk!"

A hozzátartozók, barátok, ismerösök úgy igyekeztek segíteni, hogy karácsonyra még több és gazdagabb csomagot küldtek, amelyekben egész kis karácsonyfák, az otthoni, szokásos karácsonyi ételek (kalács, szaloncukor, édességek, gyümölcs), és disznóvágásból származó finomságok voltak. Az egykori kitelepítettek meghatottan emlékeztek vissza a karácsonyi „csomagdömpingre”, ami a rokoni, baráti szolidaritás, együttérzés kifejezése volt, és segített elviselni, túlélni a számkivetettség magányosságát, kiszolgáltatottságát, nyomorúságát. ${ }^{46}$

A szilvesztert is megünnepelték, szintén Veress Dezsőné leveléből tudjuk, hogyan:

„Közben a Gazdaság is nagyon forszírozta, a rendörség is nyomott, hogy mint kulturfelelös, rendezzek egy jó szilveszteri müsort a felnőttekkel. A Gazdaság fü-

46 A csomagküldés az otthon maradottak számára is nagy áldozatot jelentett, hiszen az ötvenes évek elején Magyarországon, a beszolgáltatások, padlássöprések, az engedélyhez kötött disznóvágások idején óriási volt az élelmiszerhiány, a szegénység. tőanyagot, függönyt, színpadhoz deszkát, petróleumot, villanyvilágításhoz akumolátort, körtéket stb.-t adott, a rendőrség engedélyt étel és ital beszerzésre, virslire, borra, táncra. Jó müsor volt. A János vitézből a tündérek kara volt balettkarba, 6 hátulsó kartáncos és egy első, szólótáncossal, rózsaszín krepp-papír balett-ruhákban. Büvészmutatványokat adtak nagyon ügyesen. Operett-részleteket énekeltek a Szibillből és a Varázskeringőből, magyarnóták voltak szívfájdító hazavágyakozással, szép magyar tánc, egy-két villámtréfa, egy balettparódia, amit lány balettruhában, nagy masnikkal a hajukban fiatalemberek jártak, utánozva a lányokat. Aztán volt nőimitátor, príma jó volt. Éjfélkor halkan húzták a „cigányok” (közülünk valók) a Szózatot, és e halk zenekíséret mellett a Sass Pityu gyönyörüen elszavalta a Szózatot, utána mindannyian elénekeltük a Himnuszt. Mi aztán hazajöttünk a Bácsi-tanyára, de a fiatalság együtt maradt az iskolában reggel 4-ig. Táncoltak."

\section{Egészség, betegség, halál}

A levelekben és a visszaemlékezésekben egyaránt vissza-visszatérő téma a sok szenvedést okozó időjárás (a nyári hőség, a téli hideg, a hatalmas sár, a legyek), ami ellen - a tábor körülményei között - alig volt lehetőség védekezni. „Aug. 14-én d.u. kezdem írni e levelet. Rettenetes hőség van és a bogarak (legyek) esznek meg. Szinte lehetetlen a védekezés. Höség ellen nincs hová bújni, a legyek ellen nincsen semmi irtó szer" - panaszolja Veressné. Tavasszal és ősszel a hatalmas, szinte járhatatlan sár jelentett nagy gondot: „itt akkora sár van, hogy a bő nadrág liffeg és sáros lesz. Képzeljétek, szeptember óta egyfolytában esik az eső, tegnapelőtt a csizmám szárán folyt be a sár, agyagos a talaj, nem ereszti jól át a vizet és borzalmak borzalma pl. kijutni a WC.-re, eljutni az iskolába vagy ha pláne munkára menni."

Fütőanyagot (fütéshez, főzéshez) a gazdaság nem biztosított, a „lakásnak" használt istállók, hodályok, a mennyezet, nyílászáró nélküli, huzatos házak kifüthetetlenek voltak. A „telepesek” rá voltak kényszerülve, hogy fütésre való anyagot „szerezzenek”, hogy ne fagyjanak meg. Napraforgószárat, szalmát, lebontott házak faanyagát, titokban kivágott fát, minden útjukba eső gallyat összeszedtek. Nagy gond volt a megfelelő ruha, cipő hiánya, amit szinte kizárólag a hazulról érkező csomagok segítségével tudtak pótolni.

„És ugye én bakancsot kaptam - emlékezett vissza Dukai Róbertné, aki akkor 14 éves volt -, és bizony, mikor az édesapámmal már az istállóban dolgoztunk, és akkor a térdig érő hóban bakancsban mentem. És azért az nem volt olyan szoros, mint a rendes bakancs, tehát nem olyan, mint a magasszárú cipő. Ott oldalt, vagy a cipőfüzőnél, ahol megkötöttük, elállt az ember lábától, oda belement a hó, az beleolvadott, a hóba megfagyott, tehát annyira agyonfagytak a lábaink, és egyáltalán mi magunk is. Mert volt úgy, hogy eltévedtünk az éjszakába, hiába sütött a hold, hiába volt világos, egyszerüen elindultunk a borzasztó nagy hóviharban, és nem láttuk, nem találtuk meg az istállót, ahol dolgoztunk." 


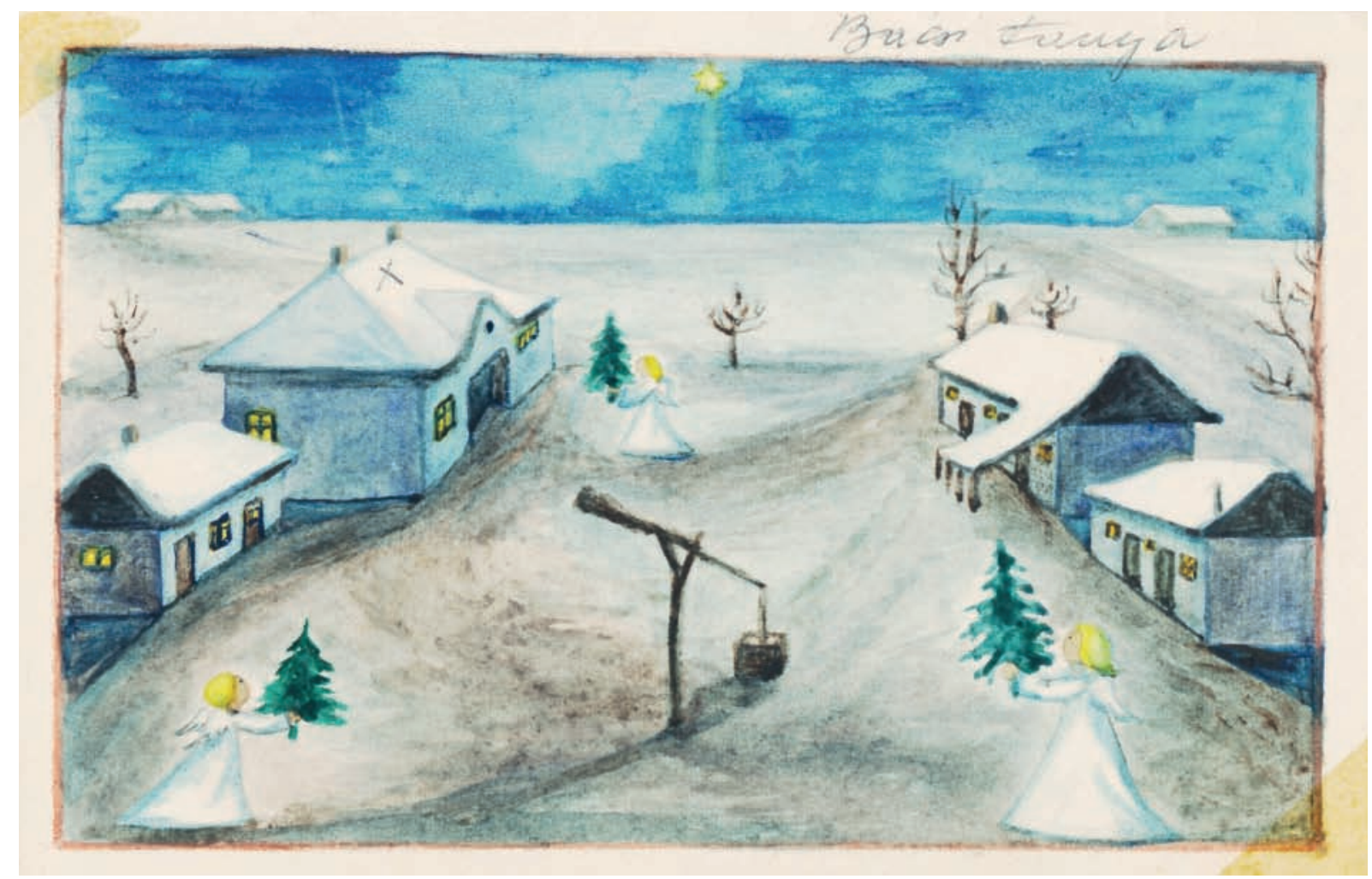

5. ábra. Elepen készített karácsonyi képeslap a Veress család levélgyüjteményéből.

Fertőző megbetegedés (pl. hasmenés, fertőző májgyulladás) valamennyi táborban előfordult. Nagyobb, a táborlakókat megtizedelő járvány azonban sehol sem volt. A táborok egészségügyi felügyeletét a hetente Veressné leveléből tudjuk, hogy Elepre péntekenként - kijáró orvos látta el, ill. a táborbeli segítsége: kitelepített orvos, asszisztens, ápolónővér. Más napokon azonban nem volt kihez segítségért fordulni: Meghalt az első társunk. Egy bácsi, akit alighanem a guta ütött meg. ${ }^{47}$ Minden pénteken jön orvos ide Debrecenböl, de a bácsinak peche volt, mert szombaton érte a baj, pár napig halódott és el is végezte, pap nélkül fekszik a hortobágyi vadvirágok alatt. ${ }^{48} \mathrm{Az}$ orvos döntött a kórházi beutalásokról is. A debreceni kórházban az emberséges orvosok igyekeztek minél tovább bent tartani a betegeket, a szülő nőket, hogy minél később kelljen visszamenniük az embertelen körülmények közé. A nagyatádiak különösen örültek, mert egy atádi származású fiatal orvos is dolgozott a kórházban, aki megpróbált mindenben segíteni a hozzá kerülő betegeknek. Különösen sok asszony került kórházba nőgyógyászati megbetegedésekkel: „B. kertészné is, $A$.-né (az én kolléganőm) és még többen vérzünk az asszonyok közül, 2-nek leszakadt a munka közben a méhe, az atádi K.M. méhgyulladást kapott. Szépen nézünk ki asszonyok! Általában elég sok a beteg. A fogaink is mennek tönkre. Hát így." (1953. május 26.)

47 Szélütés, stroke

48 1952. június 29
Mélyen megrendítő volt az elepi halál. A hozzátartozókat sújtó gyászt nem kísérhette a szabad életben megszokott temetési szertartás, az egyházi búcsúztatás, a rokonok, ismerősök, szomszédok együttérzést, lelki támaszt nyújtó jelenléte. Egy fiatalasszony haláláról olvashatunk Veress Dezsőné 1953. március 8-i levelében:

„Már napok óta nagy betegünk volt a tanyában. Egy szentgotthárdi asszonyka. Tegnap egész nap agonizált, az éjjel meghalt. Tegnap imádkoztunk mellette, ma gyertyát gyújtottunk, az egyik asszony meghintette szentelt vízzel, az emberek deszkából már koporsót ácsoltak, beleraktuk, másik asszonynak volt selyempapírja, rózsaszín, - azt szemfedőnek használtuk, aztán jött a szekér, kezébe adtuk szegénynek Jutka, Peti és Anyuka képe fölül az elepi barkát, aztán „kikísértük” az iskola faházába. Az ura és 10 éves kisfia álltak, mi pár vályogtéglára raktuk, imádkoztunk, aztán hazajöttünk. A szekér megfordult, hozta az ebédet, szegény asszonykát holnap elföldeljük. Ez már a negyedik a tanyánkon!"

\section{Rabok és „szabadok” - sokféle árnyalat}

Érdemes egy pillantást vetni arra, hogyan emlékeznek a kitelepítettek a gazdaságban dolgozó szabad munkásokkal, a környéken lakókkal, illetve az őket őrző rendőrökkel való viszonyukra, kapcsolatukra.

A kitelepítés idején 14 éves kislány számára az egyik legmegdöbbentőbb tapasztalat volt az, hogy az ottani szabad munkások őket „bünözőknek” tekintették, és tartottak tőlük, kerülték őket: 
„[...] ők mondták [a szabadok], hogy úgy vagyunk beállítva, hogy bünözők vagyunk. De, hogy milyen bünözők, azt nem tudom, de bünözők, és mivelünk ne álljanak szóba, mert mi olyan emberek vagyunk, hogy... lgy voltunk beállitva. [...] Habár mi beszélgettünk, és mondtuk, hogy nem, mi deportáltak vagyunk, minket igy hurcoltak el, meg a szüleink végett, vagy a származás végett. Vagy a munkahely végett. Vagy... valami ilyesmi..."49

Ahogy teltek a hónapok, a földeken vagy az állatok mellett együtt dolgozó emberek közötti beszélgetések révén feloldódott a mesterségesen szított ellenszenv, amit az együttérzés, segítőkészség, sőt, akár barátság is felválthatott. Szintén Dukai Róbertné mesélte, hogy azzal a szabad munkással, akivel hónapokig együtt dolgoztak az istállóban a tehenek mellett, a kitelepítés után még évekig leveleztek a szülei. Többen viszszaemlékeztek arra is, hogy a környéken élők révén sikerült olykor-olykor élelmiszerhez jutni, vagy „fekete” - azaz a K-örsöt megkerülö, nem cenzúrázott levelet vagy csomagot - ki- vagy becsempészni a táborból, táborba. Ugyanakkor ennek ellenkezőjére is van példa. Veressné egyik leveléből kiderül, hogy egy hónapi levélelvonást kapott büntetésül azért, mert egy „fekete levelét" elfogták: A postamesternő éber komcsi, és beküldte a parancsnokhoz. Kihallgatás, kiabálás, védekezés, büntetés. (1952. november 24.)

Többféle árnyalat rajzolódik ki a levelekből és a visszaemlékezésekből a tábort őrző rendőrökkel kapcsolatban is. „Jó” és „szörös szívü” rendőrökre is emlékeztek. Kitapasztalták, hogy kik az elnézőbbek, vagy esetleg megvesztegethetőek, akik „nem néztek arra”, ha ételszerzés miatt néhányan kiszöktek a táborból, vagy fát vágtak a tábor területén kívül eső facsoportból. Arra is emlékeztek ugyanakkor, hogy egy 18 éves fiút a rendőrök - bosszúból - úgy megvertek, hogy majdnem belehalt. Veress Dezsőné 1953. május 26-i levelében számol be arról, hogy „húsvéttól pünkösdig nem osztott levelet az új és nem nagy szívü örmester parancsnokunk. Azt hittem megörülök már" - írta. Az otthonról érkező levelek hiánya, a büntetésből megvont levelezés rendkívüli módon megviselte a kitelepítetteket, hiszen ez volt az egyetlen, nagyon vékony szál az otthoniakkal, a szabad világgal való kapcsolat fenntartására.

Selmeczy Miklós visszaemlékezésének egy döbbenetes részlete a végletes, kegyetlen rendőri brutalitást példázza - ilyen is volt:

„Mikor a mászás és az első lépések korában voltam, egyszer Édesanyám két másik nővel hozott a gyerekeknek paradicsomot, és én is kaptam belöle. Gondolom, akkor ehettem elöször paradicsomot. Amire én emlékszem, hogy a rendőrök megjelennek a barakkban, kirángatják az Édesanyámat és a két nöt, és az őrházukba viszik öket. Többen voltunk ott kisgyerekek, és persze mindnyájan üvöltésben és sírásban törtünk ki, és a rendőrház ablaka elé rohantunk. A rendőrök kijöttek elzavarni, de mi csak ültünk a földön és hangosan

49 Dukai Róbertnével készített interjú részlete. sírtunk. Ma is emlékszem a ház sárga falára, és arra, hogy az ablak elérhetetlenül magasan volt nekünk. Nekem hosszú időnek tünt, míg a Mamámat és a nőket kiengedték. Később, nagyobb koromban tudtam meg, hogy Édesanyám szerint mi, síró és ordító gyerekek mentettük meg őket a bántalmazástól és erőszaktól. Mint elmondta, így a büntetésük csak az lett, hogy hoszszú ideig fél lábbal kellett állni a fallal szemben, míg az orruk a falhoz ért és a rendőrök fenyegették őket. A paradicsomot a földröl "lopták” nekünk munka közben, de valaki elárulta őket."

\section{Hogyan tovább? - a kitelepítés után}

Sztálin 1953. március 5-én bekövetkezett halála után a Szovjetunióban politikai és személyi változások következtek be, és a magyarországi változások is ezt az új irányvonalat követték, természetesen a szovjet pártvezetés utasítására és irányításával. A közvélemény Nagy Imre 1953. július 4-én elhangzott, a kormány programját ismertető miniszterelnöki beszédéből értesülhetett az új szakasz irányelveiről, és ezzel összefüggésben az internálás és az internálótáborok felszámolásáról. Az amnesztiarendelet intézkedett a hortobágyi zárt táborok feloszlatásáról és az ott elhelyezett személyek kényszerlakhelyhez kötöttségének megszüntetéséről. A táborok lakóinak ügyét rendező bizottság 1953. augusztus 3-án kezdte meg munkáját, 1953. október 22-ig 7281 személy „kényszerlakhelyhez kötöttségét" szüntették meg. A családok lehetőséget kaptak arra, hogy szerződést kössenek a hortobágyi állami gazdasággal, de mindössze 107 család, 207 fö maradt ott.

Veress Dezsőné 1953. július 12-i levelében, a rendelet kihirdetése után azonnal írt az édesanyjának:

„Ma egy órával ezelött volt egy gyülés, kihirdették Nagy Imre és Rákosi beszédét. Közben persze mi már sok mindenröl tudtunk. Persze azt reméltük, hogy hamarabb jön és gyorsabban bonyolódik a sorsunk, de úgy látszik, hogy a betakaritást itt kell megélnünk, ami elég természetes is, ha innen nézzük a dolgokat, mert rengeteg termés maradna itt, - munkás hiányában pusztulásban. - Nagyon boldogok vagyunk, hogy újra szabad emberek lehetünk. Az emberekkel alig lehet bírni, el se tudjátok képzelni a boldogságot, pedig nem érte őket váratlanul, hiszen állandóan ezt várták, erröl beszéltek. Persze rendelet még nem jött s így nem tud biztosat senki, hogy ott „kinn” milyen sors vár ránk, de mégis szeretnénk elkerülni innen, bár itt nagyon „fog” a Gazdaság bennünket, mindent ígér és hiszem is, hogy sokan gondolkoznak is rajta, hogy ne maradjanak-e."

Pár nappal később barátnőjének (akit családjával együtt 1952 októberében Buzsákra telepítettek ki Nagyatádról) írt leveléből jól érzékelhető az az érzelmi hullámzás, amit az új hírek, a szabadulás ígérete, ugyanakkor a jövővel kapcsolatos bizonytalanság, félelmek keltettek az emberekben:

Képzeld el a 900 egynehány embert, amint dobálják a hírek hol az érzelem hegyek tetejére, hol az érzelem völgyek legmélyére. Már előbb is a jó hírek és 
rossz hírek citeráztak az idegeinkkel, de most Nagy Imre beszéde óta, túlfeszült a hangulat. Néha azt hiszem, hogy álmodom, néha azt hiszem, hogy rossz vicc, néha remélek és tervezek, néha pesszimista módon feketén látom a leendő rendeletet és a jövőt. Azóta lelohadtak ugyan a vérmes reményeink, de „vérmes" nélkül is gyönyörü, hogy szabadok leszünk. El se tudjátok talán képzelni, hogy milyen érzés ez! Szinte azt se tudom, hogy mit kezdek a szabadsággal. Csak már jönne ki a rendelet, hogy tudnánk, hogy milyen formában és arányban fog megtörténni. Benneteket is érint ugye? (1953. július 15.)

Ugyanakkor az amnesztia rendkívül sok megszorítást és a kitelepítettekre nézve hátrányos intézkedést tartalmazott. Érdemes idézni az 1953. augusztus 1-jén keltezett felszabadítási „Ütemterv”-ből annak a közleménynek a szövegét, amelyet a telepesek előtt a következő napokban felolvastak: „A Minisztertanács határozata értelmében a kényszerlakhelyhez kötést megszüntető bizottság megkezdte munkáját. A megszüntetés folyamatosan október 31-ig történik. Elöször a beteg, munkaképtelen, elaggott és az állami gazdasággal szerződést kötött személyek, terhes és többgyermekes anyák és a jó munkát végzett személyek helyhezkötése lesz megszüntetve. A bizottság kiadja a helyhezkötést megszüntető határozatot és a jelenlegi lakhelyükre szóló lakásbejelentő szelvényt. ${ }^{50} \mathrm{~A}$ bizottság a Minisztertanács határozata alapján közli, hogy jövőbeni lakhelyüket az összes állampolgárokra vonatkozó jogszabályok figyelembevételével választhatják meg. Ez azt jelenti, hogy letelepedési engedélyhez kötött városokban, úgymint Budapesten, Miskolcon, Sztálinvárosban, Komlón, Várpalotán, valamint a déli és nyugati határövezetben levő helységekben csak akkor lakhatnak, ha ott letelepedési engedélyt kapnak. A letelepedési kérelmeket a hatóságok igen szigorúan bírálják el, tehát azt ne is kérjék, mert úgy sem fogják megkapni. Ugyancsak felhívja a bizottság a figyelmüket, hogy a régi lakóhelyeiken maradt és igénybevett ingó, valamint ingatlan vagyontárgyaik visszaadását a hatóságoktól ne követeljék, mert azokat nem kapják vissza. [...."51

A hortobágyi zárt táborokból szabadulók tehát nem mehettek vissza egykori lakóhelyükre, otthonaikba, hanem szinte minden nélkül - mindössze a kényszermunkatábor viszontagságait túlélt, megmaradt holmijuk töredékeivel - kellett valahol, új, idegen helyen újrakezdeniük az életüket. Szabadulólevelet kaptak az otthontalanságba. ${ }^{52}$ Mindezt úgy - bár ők ezt nem tudták, legfeljebb sejthették -, hogy a következő években a hatóságok, a titkos rendőrség ügynökeinek, informátorainak folyamatos jelentésein keresztül „a legnagyobb éberséggel" megfigyeltették őket. Az Országos Rendőrkapitányság 1953. október 13-án keltezett utasítása ugyanis minden rendőrőrsöt kötelezett arra,

50 A „telepesek” tehát most, kényszerlakhelyük megszüntetése előtt közvetlenül ,jelentkeztek be" lakhelyükre, azért, hogy aztán onnan „hivatalosan” ki tudjanak jelentkezni.

51 Hantó, 2006: 409

52 Saád, 2005: 325. hogy a „kulákelemekről”, a „volt tőkésekről” és „kizsákmányolókról”, sőt keresőképes gyermekeikről is kartotékszerű nyilvántartást vezessen. A megfigyelés, az adatgyűjtés egészen a rendszerváltásig folyt. ${ }^{53}$ Bárhová költöztek tehát a volt kitelepítettek, a róluk vezetett kartoték mindenütt utolérte őket, eljutott a helyi pártvezetéshez, akik továbbították azt a munkahelyi vezetőknek. Ennek következménye volt az, hogy nagyon nehezen kaptak munkát, illetve, ha el is tudtak helyezkedni, egy-két hónap múltán - addigra érte utol őket a róluk vezetett dosszié - elbocsátották őket. Értelmiségi munkát, még ha diplomájuk, szakképzettségük szerint alkalmasak voltak is rá, nem kaphattak, szinte kizárólag fizikai, s azon belül is alkalmi munkára vették fel őket. A gyerekek neve mellé az iskolai iratokban pedig bekerült az „X”, ami azt jelentette, hogy „osztályidegen”. Továbbtanulásukat tehát - függetlenül az iskolai teljesítményüktől, eredményeiktől - nem támogatták, és a legtöbb esetben teljesen el is lehetetlenítették. ${ }^{54}$

A nagyatádiak, ha tehették, igyekeztek legalább egykori lakóhelyük közelében letelepedni (pl. Bolhásra, Somogyszobra, Böhönyére költöztek többen), és albérletben, esetleg rokonoknál húzták meg magukat, s próbáltak munkát találni. Egyik interjúalanyom mesélte, hogy apai nagynénje fogadta be a családjukat Zala megyében. Édesapja néhány hónapig „bírta” ezt a helyzetet (közben Zalaegerszegre járt el dolgozni), aztán úgy döntött, hogy megpróbálnak hazajönni. Február táján bekopogtattak saját egykori házukba, amelyben akkor egy rendőr lakott a családjával. A lakó nem engedte be őket, és a helyzet annyira elfajult, hogy a nagyatádi tanácselnök személyesen utasíttatta ki őket a községből, durván, megalázó módon. Végül baráti családoknál laktak hónapokig, és csak nagy nehezen sikerült visszajutni a saját - lepusztított, kirabolt - lakásukba.

A Veress házaspár Zsámbékra költözött, mert gyermekeik a nagymamával együtt akkor már ott laktak, ${ }^{55}$ és Nagyatádra amúgy sem mehettek volna viszsza. Veress Dezső egy 1953 őszén, tehát közvetlenül a kitelepítés után, a belügyminiszterhez ${ }^{56}$ írt levelében sérelmezi ezt az eljárást:

„Vajjon összeegyeztethető-e ezen intézkedés a kormány programjával, a kormányelnök július havi kijelentéseivel? A kitiltás újabb sérelmet jelent, a szocialista törvényesség megsértését, mert személyes szabadságomban korlátoz, ennek alapját szolgáltató cselekedet, tevékenység, tehát minden ok nélkül s ezzel nem csak másodrendü polgárrá degradál, de anyagi létem lehetőségét is veszélyezteti."

53 Hantó, 2006: 43-44

54 A későbbiekben, a hatvanas-hetvenes években e téren már történtek változások. Többen vissza tudtak térni eredeti szakmájukhoz (pl. ügyvéd, tanári munkakörökhöz), és a kitelepítettek gyerekei (akár kerülő utakon, például úgy, hogy előbb szakmát szereztek, és mint munkások) - bejutottak felsőfokú intézményekbe.

55 Az 1952 októberi kitelepítésük után, decemberben anyai nagybátyjuk költöztette el őket Zsámbékra. Így közelebb kerültek a Budapesten lakó rokonokhoz, akik jobban tudták segíteni és felügyelni a magukra maradt gyerekeket és idős nagymamájukat.

56 Gerő Ernő 
A jogilag pontosan - dr. Veress Dezső ügyvéd volt - megfogalmazott mondatok valószínüleg soha nem értek célba, talán végül el sem küldte a levelet, belátva azt, hogy hiábavaló bármiféle törvényességet, sőt, akár csak az emberséges eljárást elvárni egy olyan hatalomtól, amely semmiféle törvénytelenségtől nem riad vissza. Ezt támasztja alá az a tény is, hogy Veress Dezső személyi igazolványába két évvel később, 1955. (!) augusztus 5-én került bele a rendőri bejegyzés, amellyel a nagyatádi járás egész területéről kitiltották (a BM. ORK.0559/A-1953. számú határozatra hivatkozva). A kitiltást 1957. február 26-án oldották fel. Veress Dezső akkor visszaköltözött Nagyatádra, és hosszú hónapok kitartó utánjárásával el tudta érni, hogy le is telepedhessen itt feleségével együtt, és az ügyvédi foglalkozásához is visszatérhessen. (A kitelepítés időszaka alatt - 1953-ban - az Ügyvédi Kamara ugyanis kizárta őt a testületből „a gyakorlatban történő akadályoztatása miatt". A kizárást 1957-ben visszavonták, s újra fölvették a kamarába. Ez volt a feltétele annak, hogy ügyvédként, a nagyatádi ügyvédi munkaközösség tagjaként dolgozhasson.)

Dukai Róbertné 15 éves múlt, amikor visszakerülhettek Nagyatádra. A nyolcadik osztályt még be sem fejezhette, amikor kitelepítették családjukat, s miután visszatértek, tudta, hogy semmi esélye sincs arra (nővérének sem), hogy továbbtanulhassanak. Így ő a fonalgyárban, nővére a konzervgyárban helyezkedett el betanított munkásként.

„Na, most a gyárban - emlékezett vissza - én mindjárt gépre kerültem dolgozni, és nagyon örültem annak, és nagyon igyekeztem szorgalmas lenni, mert mi ketten tartottuk el [magukat és a szüleiket] - A testvérem, a Zsuzsi, az a konzervgyárba ment dolgozni, őt oda vették fel. [...] '54. július 25-én kerültem be a cérnagyárba, és [...] annyira igyekeztem dolgozni, hogy el ne küldjenek, mert akkor is úgy volt, hogy szerződésre vettek fel bennünket, úgy egy hónapra. De hát, ugye, be kellett tanulni, és ki milyen szorgalmas volt, ki hogyan teljesített, ugye, normára kellett dolgozni, a jókat nem küldték el, a rosszakat elküldték. És hát mindig annyira igyekeztem dolgozni. És hát én ott maradtam, ott ragadtam. Nem ez volt a célom, szerettem volna más lenni, vagy tanulni, de... És itt is úgy voltam, hogy mindig a szebbik oldalát néztem ennek a dolognak, mert tudtam, hogy nem mehetek sehova, nem vesznek fel sehova iskolába, és megpróbáltam úgy dolgozni járni, hogy megtaláljam benne a szépet. Mert ha csak mindig a rosszat néztem volna, akkor borzasztó lett volna ezt végigcsinálni."

A volt kitelepítettek hivatalosan 1956-ban, a déli határsáv megszüntetése után térhettek vissza lakóhelyükre. A 29/1956. sz. rendelet szerint a megszűnt déli határövezetből a nem bűntett miatt kitelepített személyek korlátozás nélkül visszatérhettek lakóhelyükre, sőt, családonként 5.000 Ft-ig terjedő mértékű segélyben is részesülhettek. Lakásuk, házuk rendbe tételéhez további, legfeljebb 10.000 Ft kölcsönt is igényelhettek. Rendezték az érintett személyek vagyonjogi követeléseinek kérdéseit is. (29/1956. MT. sz. rendelet a volt déli határsáv létesítésével érintett egyes személyek vagyonjogi igényeinek érvényesítéséröl, MK. 1956/79. sz. (1956. szeptember 8.). Ismertette: Szabad Nép, 1956. szeptember 9. ${ }^{57}$ Megbélyegzettségük azonban egészen a rendszerváltásig megmaradt.

\section{„Ez zavar csak, a miértje.”}

Súlyos kérdés, amely a levelekben, az interjúk során, a visszaemlékezésekben egyaránt újra és újra előkerül: miért történt mindez? A történészek megállapításai helyett álljon itt most néhány részlet arra vonatkozóan, hogy azok, akik megélték a sorseseményként rájuk zúduló kitelepítést, hogyan próbálták azt feldolgozni, és valamiféle, önmaguk számára is ésszerü magyarázatot, vagy inkább értelmet találni a velük és a családjukkal történtekre. Mindezt annak érdekében, hogy szétzilált önképüket, életükröl alkotott képüket helyreállíthassák, hiszen azon, ami történt nem, csupán annak az értelmezésén változtathattak.

Veress Dezső egy keltezetlen, ám a szövegöszszefüggésből kikövetkeztethetően valószínüleg 1953 őszén, már a Hortobágyról való szabadulás után levelet írt a belügyminiszternek, ${ }^{58}$ amelyben a vele és családjával történtek okaira kérdez rá, és az eljárás törvénytelen, igazságtalan voltát sérelmezi. A levél befejezetlen, és valószínüleg el sem küldte végül a címzettnek, hiszen csupán újabb retorzióra számíthatott volna egy, a törvényességet kiiktató „jogrendben”:

„Kitelepítésemkor nem közölték velem, hogy mi okból történt ezen kényszerintézkedés, és annak okáról - bár igyekeztem utána érdeklődni - a mai napig sem tudtam semmi biztosat megtudni. Meggyőződésem szerint a velem történtek egyik esete volt azoknak a törvénytelenségeknek, illetve visszaéléseknek, vagy hatalmi túltengéseknek, amelyekröl Nagy Imre elvtárs, a minisztertanács elnöke annak idején megemlékezett."

1964-ben, az életútján végigtekintő, azt összegző írását azonban ezzel a megbocsátó gesztussal zárja:

„Ha voltak is megpróbáltatások, azok a szerencsésnek mondható eredmények mellett elmellőzhetőknek jelentkeztek s mert történhettek volna a dolgok sokkal kellemetlenebbül is, azokat feleleveniteni nem is akarom. A nagy változások idejét éljük, ilyenkor az áldozatok elkerülhetetlenek."

Selmeczy Miklós már idézett visszaemlékezésében így összegzi a vele és családjával történteket:

„Azt már az 1988-as „Törvénysértés nélkül” címü (Gulyás Gyula, Gulyás János) filmből tudtam meg, hogy 1950-ben azért kezdték a deportálást a Dél-Dunántúlon, mert Rákosi meg akarta mutatni, hogy talált valódi büntársakat az akkor ellenségnek kihirdetett, „rossz kommunista” Jugoszláviával. Akkor tudtam meg, hogy a rendszer szerint mi voltunk a „Tito láncos kutyái.” Ezt a megnevezést gyakran hallottam az iskolában gyerekkoromban az 50-es évek kapcsán, de 38 éves koromig nem tudtam, hogy mit is jelent, és nem is sejtettem,

57 Bencsik, 2011

58 Akkor Gerö Ernő volt a belügyminiszter, 1953. július 4.- 1954. június 6-áig. 
hogy a Rákosi-rendszer szerint én magam is, babakoromban a „Tito láncos kutyája” voltam. [...] Egy kívülállónak furcsának tünhet, hogy Lenin-tanyára szívesen járok vissza, és az ott töltött időt most a távlatból életem egy szép korszakának tartom. A mi családunkban ez nem tünik különlegességnek, mert a szüleim mindent felülmúló és magába foglaló szeretete, és a család közelsége nekem ott is tökéletes biztonságot és békét adott. [...] Most, visszanézve, persze sok mindenért nehéz ma a szívem, és vagyok szomorú, de inkább sajnálatot érzek, és semmiképpen nem haragot. Ennek oka már felnőttkoromból származik, amikor megtudtam a tényeket, megértettem az összefüggéseket, és megtudtam mások sorsát is. Fel kellett nönöm ahhoz, hogy értékelni tudjam az ott töltött időt és megpróbáltatásokat. Ma hálát adok mindezért, mert amit ott kaptam, az elkísért az életben, segített hitem erösödésében, és egy fontos része annak, ami vagyok."

$S$ végül Dukai Róbertné szavait idézem:

„....mindig volt erőm talpra állni. És azért én mindig úgy nézek, úgy gondolok vissza a Hortobágyra, [...] én úgy gondolok arra a 17 hónapra, amit ott eltöltöttem, hogy egy életre megtanított a kitartásra, az elviselésre, és arra, hogy a szebbik oldalát nézzem. És annyira büszke vagyok magamra, mert én annyi sok mindent megtanultam. Megtanított az élet rá, hogy tényleg nagyon kevés dolog van, amit nem tudok megcsinálni egyedül, és most veszem a hasznát ezeknek a dolgoknak, meg hogy egyedül meg tudok állni a lábamon."

\section{Utószó}

Írásomban nem törekedhettem arra, hogy a nagyatádi kitelepítés történetét teljes egészében bemutassam. Az események szemtanúinak perspektívájából felvázolt történet azonban közelebb viheti az olvasót ahhoz, hogy a történelmi események mögött meglássa, megértse az emberi sorsokat is. A személyes dokumentumokból kibontakozó kép láthatóvá teszi a meghurcoltak mindennapjait, érzelmeit, a borzalmas körülmények között is működni képes együttérzést, a szolidaritást. Fölsejlik belőlük a fájdalmasan hiányzó, elveszített otthon képe, s mellette a börtönné vált hortobágyi tájnak a vázlata is. A levelek, visszaemlékezések történetei megmutatják azt, hogy a kitelepítettek hogyan tudták túlélni az embertelen körülményeket, a fizikai és lelki megpróbáltatásokat. S végül néhány példát láttunk arra, hogy az eseményeket átélők hogyan építették be önképükbe a velük történteket, éppen saját belső integritásuk, önmaguk megőrzése érdekében. A történet egyéb részleteinek kibontása további tanulmányok feladata lesz.

Hálás köszönettel tartozom a dokumentumok átadóinak és minden beszélgetőtársamnak a sok-sok órás beszélgetésekért, a nehéz, szomorú emlékek fölidézéséért, s a bizalomért, hogy mindezt megosztották velem, és rám bízták, hogy tovább adjam őket.

\section{Irodalom}

Bank B., GyarmatI Gy. És Palasik M. 2012: „Állami titok”. Internáló- és kényszermunkatáborok Magyarországon 1945-1953. Állambiztonsági Szolgálatok Történeti Levéltára, L'Harmattan Kiadó, Budapest.

BENCSIK P. 2011: A szabad mozgás korlátozása az ötvenes években és az 1956-os forradalom elötti utazási reformok. - In: Betekintő, 2011/1. Budapest.

FüzEs M. (szerk.) 2002: Dokumentumok a hortobágyi zárt munkatáborokról 1950-1960. - Kitaszítottak II. kötet. Budapest, Alterra Svájci-Magyar Kiadó Kft.

HANTÓ Zs., TAKÁCS J., FüZES M. ÉS SAÁD J. 2001: „Magukkal fogjuk megzsírozni a földet". - Kitaszítottak I. kötet. Budapest, Alterra Svájci-Magyar Kiadó Kft.

HANTó Zs. 2006: Családok munkatáborokban (1.). - Kitaszítottak III. Magyar Ház Könyvek. Budapest, Magyar Ház Kft.

KISS L. 2005: Zárt táborok a Hortobágyon és a Nagykunságon 19501953. - In: Saád J. (szerk.): Telepessors. Budapest, Gondolat Kiadó, pp: 13-50.

KUNT G. 2015: „Nem vagyok politikus, csak egy buta csitri” - a kitelepítés kamaszszemmel. - In: Horváth S. és Kovács J. (szerk.): Állami erőszak és kollektivizálás a kommunista diktatúrában. Budapest, pp: 205-226.
NovÁK I. 2014: Ítélet nélkül, ártatlanul. Fejezetek a csurgói járásból 1950-53 között, a hortobágyi zárt kényszermunkatáborba elhurcoltak életéről. - A Gyékényesi Krónika c. községi közéleti lap kiadványa. Gyékényes.

ORgovÁNYI I. 2001: A déli határsáv 1948 és 1956 között. - In: BácsKiskun megye múltjából. Évkönyv 17. Kecskemét, Bács-Kiskun Megyei Önkormányzati Levéltár.

SAÁD J. 2010: Hortobágy. A magyar Gulág. - In: Rubicon XXI. évf. 207. sz./6: 4-20.

SAÁD J. (szerk.) 2005: Telepessors. - Budapest, Gondolat Kiadó.

SZÉCHENYI K. 2015: Megbélyegzettek. - Budapest, Helikon Kiadó.

VICZIÁN Zs. 2010: „Régen lev. lapokon láttam ilyent”. Levelek a kitelepítésből. - In: Budapesti Negyed 68. (nyár): 162-180.

Internetes hivatkozások:

http://www.betekinto.hu/sites/default/files/betekinto-szamok/2011_1_ bencsik.pdf. letöltés: 2020. 05. 21 